\title{
Modelling the direct effect of aerosols in the solar near-infrared on a planetary scale
}

\author{
N. Hatzianastassiou ${ }^{1,2}$, C. Matsoukas ${ }^{2,3}$, A. Fotiadi ${ }^{2,4}$, P. W. Stackhouse Jr. ${ }^{5}$, P. Koepke ${ }^{6}$, K. G. Pavlakis ${ }^{2,7}$, and \\ I. Vardavas ${ }^{2,4}$ \\ ${ }^{1}$ Laboratory of Meteorology, Department of Physics, University of Ioannina, 45110 Ioannina, Greece \\ ${ }^{2}$ Foundation for Research and Technology-Hellas, Heraklion, Crete, Greece \\ ${ }^{3}$ Department of Environment, University of the Aegean, Mytilene, Greece \\ ${ }^{4}$ Department of Physics, University of Crete, Crete, Greece \\ ${ }^{5}$ Atmospheric Sciences, NASA Langley Research Center, Hampton, Virginia, USA \\ ${ }^{6}$ Meteorological Institute, University of Munich, Munich, Germany \\ ${ }^{7}$ Department of General Applied Science, Technological Educational Institute of Crete, Greece
}

Received: 24 July 2006 - Published in Atmos. Chem. Phys. Discuss.: 25 September 2006

Revised: 15 December 2006 - Accepted: 30 May 2007 - Published: 25 June 2007

\begin{abstract}
We used a spectral radiative transfer model to compute the direct radiative effect (DRE) of natural plus anthropogenic aerosols in the solar near-infrared (IR), between $0.85-10 \mu \mathrm{m}$, namely, their effect on the outgoing nearIR radiation at the top of atmosphere (TOA, $\Delta \mathrm{F}_{\mathrm{TOA}}$ ), on the atmospheric absorption of near-IR radiation $\left(\Delta \mathrm{F}_{\mathrm{atmab}}\right)$ and on the surface downward and absorbed near-IR radiation $\left(\Delta \mathrm{F}_{\text {surf }}\right.$, and $\Delta \mathrm{F}_{\text {surfnet }}$, respectively). The computations were performed on a global scale (over land and ocean) under all-sky conditions, using detailed spectral aerosol optical properties taken from the Global Aerosol Data Set (GADS) supplemented by realistic data for the rest of surface and atmospheric parameters. The computed aerosol DRE, averaged over the 12-year period 1984-1995 for January and July, shows that on a global mean basis aerosols produce a planetary cooling by increasing the scattered near-IR radiation back to space by $0.48 \mathrm{~W} \mathrm{~m}^{-2}$, they warm the atmosphere by $0.37 \mathrm{~W} \mathrm{~m}^{-2}$ and cool the surface by decreasing the downward and absorbed near-IR radiation at surface by 1.03 and $0.85 \mathrm{~W} \mathrm{~m}^{-2}$, respectively. The magnitude of the near-IR aerosol DRE is smaller than that of the combined ultraviolet (UV) and visible DRE, but it is still energetically important, since it contributes to the total shortwave (SW) DRE by $22-31 \%$. The aerosol-produced near-IR surface cooling combined with the atmospheric warming, may affect the thermal dynamics of the Earth-atmosphere system,
\end{abstract}

Correspondence to: N. Hatzianastassiou

(nhatzian@cc.uoi.gr) by increasing the atmospheric stability, decreasing thus cloud formation, and precipitation, especially over desertification threatened regions such as the Mediterranean basin. This, together with the fact that the sign of near-IR aerosol DRE is sometimes opposite to that of UV-visible DRE, demonstrates the importance of performing detailed spectral computations to provide estimates of the climatic role of aerosols for the Earth-atmosphere system. This was demonstrated by sensitivity tests revealing very large differences (up to 300\%) between aerosol DREs computed using detailed spectral and spectrally-averaged aerosol optical properties. Our model results indicate thus that the aerosol direct radiative effect on the near-IR radiation is very sensitive to the treatment of the spectral dependence of aerosol optical properties and solar radiation.

\section{Introduction}

Amongst the different factors that can cause climate change, both aerosols and greenhouse gases play an important role. Well-mixed greenhouse gases have produced a positive (warming) radiative forcing of about $2.4 \mathrm{~W} \mathrm{~m}^{-2}$ from preindustrial times (IPCC, 2001). Tropospheric aerosols on the other hand, both natural and anthropogenic, act in an opposite way in total through their direct radiative effect, by increasing the planetary albedo and cooling the surface. Aerosols may offset greenhouse-gas warming by about

Published by Copernicus Publications on behalf of the European Geosciences Union. 
25-50\% (Kaufman et al., 2002), but there is uncertainty regarding their overall radiative forcing (IPCC, 2001). Better estimates of the aerosol radiative effects on a planetary scale are required to reduce the uncertainties.

The main direct effect of aerosols is on the shortwave (SW) radiation, being much smaller in the longwave (thermal infrared) due to the rapid decrease of aerosol extinction with increasing wavelength for most aerosol types. One way to compute the SW direct effect is to use multi-component global aerosol models or general circulation and climate models that are able to represent adequately the physical structure of the Earth's atmosphere with aerosols. These models require comprehensive global microphysical, microchemical, optical, and radiative aerosol properties. Despite the progress that has been made with these models (e.g. Jacobson, 2001; Liao et al., 2004; Reddy et al., 2005; Takemura et al., 2005), there is a wide range of discrepancy between the different model results (Remer and Kaufman, 2006) and difficulties to reproduce correctly satellite observations (Bellouin et al., 2005). Another way is to use satellite observations to estimate aerosol radiative effects and forcings. This technique has become attractive lately, as modern instruments such as the MODerate resolution Imaging Spectroradiometer (MODIS), the Multi-angle Imaging SpectroRadiometer (MISR) or the Clouds and Radiant Energy System (CERES) were designed specifically to observe aerosols and the Earth's radiation budget. Such observational methods have been applied (e.g. Bellouin et al., 2005; Zhang et al., 2005) to estimate the combined direct radiative effect of both anthropogenic and natural aerosols. Yu et al. (2006) provides a thorough review of the radiative effect of aerosols from both satellite-based methods and global models. Although many problems related to satellite observations of aerosols have been resolved with the more sophisticated instruments, there are still problems as shown by discrepancies between different satellite products (Zhao et al., 2005). Another problem with the satellite-based method (e.g. Christopher and Zhang, 2002) is that it provides estimates of aerosol forcing only at the top of atmosphere (TOA), and not within the atmosphere and at the Earth's surface, where the effect of aerosols is largest.

An efficient way to compute the aerosol radiative effects is the use of radiation transfer models, but these usually include a few spectral bands in the whole SW range, which does not allow for precise calculations. Therefore, one of the important improvements is a better spectral resolution in these models. This is critical, since the optical properties of aerosols vary within this spectral range, making thus their interaction with solar radiation very sensitive to wavelength. As shown by Hatzianastassiou et al. (2004b), it is very important to perform detailed computations of aerosol forcing, using spectrally resolved aerosol properties, since inadequate treatment can result in modified aerosol forcings at TOA, in the atmosphere and at surface by 1.4, 15.7 and $7.5 \%$, respectively, on a global scale, and up to $100 \%$ lo- cally (at geographical cell-level). In this study, we use a detailed spectral radiative transfer model along with spectral aerosol properties (and also surface and atmospheric parameters) to compute the direct radiative effect (DRE) of aerosols at near-infrared wavelengths. We have used a detailed spectral radiative transfer model to match, as best possible, the detailed spectral resolution of aerosol optical properties from the Global Aerosol Data Set (GADS, Koepke et al., 1997). More specifically, the GADS aerosol properties are given at 29 wavelengths within 0.85 to $10.0 \mu \mathrm{m}$ (see Sect. 3.1). Note that we use the term aerosol radiative effect rather than forcing, since we assess here the effect of both natural and anthropogenic aerosols, while the term aerosol forcing is often used to express the radiative perturbation due to anthropogenic aerosols only. The aerosol DRE is computed at TOA, within the atmosphere and at the Earth's surface, on planetary scale, under all-sky conditions. This is an extension of the study by Hatzianastassiou et al. (2004a) dealing with the aerosol direct effect in the ultraviolet and visible (UV-visible) wavelengths. Though the aerosol effect is larger in the UV-visible than in the solar near-IR (e.g. Valero et al., 2003; Nishizawa et al., 2004), it merits evaluation in the longer wavelengths, given that about $40 \%$ of solar radiation lies in this spectral range. Near-IR radiation is significantly affected by aerosols (Bush and Valero, 2003), especially in locations with elevated concentrations of coarse aerosol particles (sea-salt and desert-dust). We clarify that our study deals with only solar radiation in the near-IR range and not with the terrestrial radiation. Moreover, note that the contribution of solar radiation at wavelengths larger than $3.5 \mu \mathrm{m}$ to the total solar energy is very small $(<2 \%)$ so that virtually there is no overlap between solar and terrestrial radiation.

In Sect. 2, we give a short description of the model and the methodology for modelling the aerosol radiative effects. The model input data are described and discussed in Sect. 3, while in Sect. 4 are given the modelled aerosol DREs. In Sect. 5 we quantify and discuss an important aerosol effect on atmospheric thermal dynamics caused by their direct radiative effects. Finally, the contribution of near-IR to the total SW aerosol radiative effect and the sensitivity of aerosol DRE to the wavelength dependence of aerosol optical properties are discussed in Sects. 6 and 7, respectively, before the conclusions (Sect. 8).

\section{Model and methodology}

The deterministic spectral radiative transfer model used here was developed from a radiative-convective model (Vardavas and Carver, 1984). The solar irradiance is computed here for the spectral interval $0.85-10 \mu \mathrm{m}$, using the spectral profile of Thekaekara and Drummond (1971), normalized to $40.1 \%$ of the solar incoming radiation using a solar constant $\mathrm{S}_{o}=1367 \mathrm{~W} \mathrm{~m}^{-2}$ (Hartmann, 1994; Willson, 1997) corrected for the Earth's elliptical orbit. Of course, the definition for 
near-IR radiation usually also covers smaller wavelengths, i.e. from 0.75 or $0.8 \mu \mathrm{m}$, but we start in this study at $0.85 \mu \mathrm{m}$ because the computations of aerosol radiative forcing are complementary to those given in the paper by Hatzianastassiou et al. (2004a) that have covered the spectral range 0.2$0.85 \mu \mathrm{m}$. The incoming total solar flux at TOA for each 1degree latitude-longitude cell, was computed as in Hatzianastassiou et al. (2004a), where it was used for the computations of the aerosol radiative effects in the UV-visible range 0.2$0.85 \mu \mathrm{m}$ under clear sky conditions. Here, we will only provide a brief description of the model for the computations in the near-IR under all-sky conditions. The treatment of radiation transfer for the near-IR wavelengths lying in the range $0.85-1.0 \mu \mathrm{m}$ is the same as that used for the UV-visible range (see Hatzianastassiou et al., 2004a), whereas the treatment for the range 1.0-10 $\mu \mathrm{m}$, divided into ten spectral intervals, will be presented here. For each wavelength and spectral interval, a set of monochromatic radiative flux transfer equations is solved for an absorbing/multiple-scattering atmosphere using the Delta-Eddington method of Joseph et al. (1976) which is an extension of the Eddington method described in Shettle and Weinman (1970) with the standard parameters $\mathrm{g}$ (asymmetry factor), $\tau$ (extinction optical depth), and $\omega$ (single scattering albedo) replaced by the following transformations

$\tau^{\prime}=(1-\omega f) \tau$

$\omega^{\prime}=\frac{(1-f) \omega}{1-\omega f}$

$g^{\prime}=\frac{g}{1+g}$

with $\mathrm{f}=\mathrm{g}^{2}$. For the clear-sky case (i.e. part of the geographical cell), we divide the atmosphere into two layers. The lowest begins at the surface and includes atmospheric gases and the aerosols, while the highest layer contains only the atmospheric gases above the aerosols. For the cloudy-sky case, the atmosphere is divided into four layers. From the bottom to the top these are: (i) the aerosol layer, (ii) the layer between the aerosols and the cloud base, (iii) the cloud layer and (iv) the layer above the clouds up to the TOA. Note that aerosols above clouds are not considered in this study, due to missing information. This introduces an underestimate of the aerosol effect in the case of absorbing aerosols above clouds (Keil and Haywood, 2003). In particular, studies (e.g. Haywood and Shine, 1997; Haywood and Ramaswamy, 1998) have shown that black carbon existing above clouds exerts a DRE that may be greater than that in clear skies by more than a factor of 10 , the magnitude of the increase being a function of the cloud optical depth, the surface reflectance and the solar zenith angle. The situation will improve with the emerging ground-based aerosol lidar network and launch of space-borne lidars and radars (Yu et al., 2006). The radiatively active gases in the near-IR are water vapour $\left(\mathrm{H}_{2} \mathrm{O}\right)$, carbon dioxide $\left(\mathrm{CO}_{2}\right)$, and methane $\left(\mathrm{CH}_{4}\right)$, whereas clouds (low, middle, and high) and aerosols are considered as well. For each layer, the total optical depth is evaluated from the individual components at the specific layer

$\tau=\tau_{\mathrm{aers}}+\tau_{\mathrm{aera}}+\tau_{m a}+\tau_{R}+\tau_{c s}+\tau_{c a}$

where $\tau_{\text {aers }}$ is the scattering aerosol optical depth, $\tau_{\text {aera }}$ is the absorption aerosol optical depth, $\tau_{m a}$ is that for molecular absorption, $\tau_{R}$ is that for Rayleigh scattering $\left(\tau_{R}=0\right.$ in the near-IR) and $\tau_{c s}$ and $\tau_{c a}$ are the cloud scattering and cloud absorption optical depths, respectively. The single scattering albedo for each layer is

$\omega=\omega_{\text {aer }}+\omega_{R}+\omega_{c}$

where

$\omega_{\mathrm{aer}}=\tau_{\mathrm{aers}} / \tau, \omega_{R}=\tau_{R} / \tau, \omega_{c}=\tau_{c s} / \tau$

while

$g=\frac{g_{\mathrm{aer}} \cdot \omega_{\mathrm{aer}}+g_{R} \cdot \omega_{R}+g_{c} \omega_{c}}{\omega}$

with $g_{\text {aer }}$ the aerosol asymmetry factor, $g_{c}$ the asymmetry factor of the cloud and $g_{R}$ is the asymmetry factor for Rayleigh scattering set equal to 0 .

For each spectral interval, $\mathrm{b}$, and for each gas $i$, the mean transmission $t_{b, i, m}$ is computed for each component $m$ of a discrete probability distribution with coefficients $p_{b, i, m}$ and absorption coefficients $k_{b, i, m}$ (k-distribution method) with the normalization condition

$\sum_{m} p_{b, i, m}=1$

and transmission for component $m$ of gas species $i$ given by

$t_{b, i, m}=\exp \left(-k_{b, i, m} y_{i}\right)$

where $y_{i}$ is the absorber amount. If there is only species $i$ which is radiatively active in interval $b$, then the transmission for the interval is

$t_{b}=\sum_{m} p_{b, i, m} t_{b, i, m}$

However, if species $i$ and $j$ are active in interval $b$, the transfer equation is solved for all possible combinations of components $\mathrm{m}$ and $\mathrm{n}$ corresponding to the species $i$ and $j$, respectively. If $F_{b}$ is the spectral flux in interval $b$, then each component $m n$ has spectral flux $p_{b, i, m} p_{b, j, n} F_{b}$ and optical depth $k_{b, i, m} y_{i}+k_{b, j, n} y_{j}$. The concept is further generalized to overlapping bands of more than two types of molecules (see Vardavas and Carver, 1984).

Reflection of incident solar radiation from the Earth's surface is treated as explained by Hatzianastassiou et al. (2005). In brief, the surface reflectivity, $R_{g}$, for each 1-degree grid cell, is computed considering the fractional coverage of the grid cell's reflecting surface by four general types of surface: 
land, ocean, snow and ice (frozen ocean). Information for fractional coverage for each surface type is obtained from ISCCP-D2 data (Rossow et al., 1996). The ocean reflectivity, $R_{o}$, is computed using Fresnel reflection corrected for a non-smooth surface, with the condition that if Fresnel reflectivity is greater than ice- or snow reflectivity, which occurs for low solar elevations, then the reflectivities of ice or snow are set equal to the Fresnel one (see Hatzianastassiou et al., 2005). Snow and sea-ice albedo values are based on recent estimates, whereas data for land albedo were derived from ERBE data for clear sky, while overcast albedos were obtained by modifying the corresponding clear-sky values for diffuse radiation conditions. A correction is applied to landsurface albedo for high-altitude mountainous areas such as Tibet, Rocky Mountains or Antarctica's plateau, resulting in a reduction of the albedo, in order to take into account the decrease of $R_{g}$ over mountainous non-forested areas, especially during winter, due to the sub-grid orography (Roesch et al., 2001). The near-IR aerosol DRE (denoted henceforth as $\Delta \mathrm{F}$ ), or more precisely the "aerosol flux change", is the effect of aerosols on the near-IR (or SW) radiation budget at TOA, at the Earth's surface, or within the atmosphere, and it is given by

$\Delta F=F-F_{\text {no-aerosol }}$

where $\mathrm{F}$ and $\mathrm{F}_{\text {no-aerosol }}$ are the net incoming (downwardupward) near-IR (or SW) radiative fluxes with and without aerosols, respectively. The DRE components $\Delta \mathrm{F}_{\mathrm{TOA}}$, $\Delta \mathrm{F}_{\text {atmab }}, \Delta \mathrm{F}_{\text {surf }}$, and $\Delta \mathrm{F}_{\text {surfnet }}$, represent the effect of aerosols on the net incoming (absorbed) radiation at TOA, within the atmosphere, and at the Earth's surface. $\Delta \mathrm{F}_{\mathrm{TOA}}$ is essentially the change of the outgoing (reflected) near-IR (or SW) radiation at TOA, since the incoming extraterrestrial near-IR (or SW) radiation is not affected by aerosols, and therefore $\Delta \mathrm{F}_{\mathrm{TOA}}$ will refer to this henceforth. Thus, at TOA Eq. (11) reads

$\Delta F_{\mathrm{TOA}}=F_{\text {no-aerosol }}^{\mathrm{TOA}}-F^{\mathrm{TOA}}$

Therefore, positive values of $\Delta \mathrm{F}_{\mathrm{TOA}}$ correspond to decreased outgoing near-IR (or SW) radiation at TOA, and increased absorbed near-IR (or SW) radiation within the atmosphere and at the Earth's surface, and vice versa.

The methodology followed here is similar to that used by Hatzianastassiou et al. (2004a). The spectral aerosol data used (i.e. aerosol optical thickness, AOT, single scattering albedo, $\omega_{\text {aer }}$, and asymmetry parameter, $\left.g_{\text {aer }}\right)$, which are essential to the spectral radiative transfer model computations, are taken from GADS. Ten aerosol components, representative of the atmosphere, are provided but we re-compute their optical properties to take into account the effects of relative humidity (see Hatzianastassiou et al., 2004a), based on actual climatological data from the Goddard Earth Observing System (GEOS) version 1 reanalysis product, provided by the Data Assimilation Office (DAO) of NASA's Goddard Space
Flight Center (GSFC). The model aerosol DRE computations also include global distribution of surface albedo and clouds from comprehensive global climatological databases (NASA Langley Research Center dataset and ISCCP). The study is performed on a global scale, on a $1^{\circ}$ latitude-longitude resolution, for winter and summer conditions, for the 12-year period from 1984 to 1995.

\section{Aerosol properties and model input data}

\subsection{Aerosol data and properties}

The required aerosol radiative properties, AOT, $\omega_{\mathrm{aer}}$, and $g_{\text {aer}}$, were taken from GADS (Koepke et al., 1997). The dataset GADS consists of aerosol particle properties averaged over space and time, and has been used in climate models and studies (e.g. King et al., 1999; Chin et al., 2002; Morcrette, 2002; Kinne et al., 2003). A detailed discussion of GADS aerosol properties was given in the study by Hatzianastassiou et al. (2004a), where the same data were used to compute the UV-visible aerosol DRE. In GADS, the tropospheric aerosol particles are described by 10 main aerosol components, which are representative for the atmosphere, resulting from aerosol emission, formation, and removal processes within the atmosphere, so that they exist as mixture of different substances, both external and internal. The GADS 10 aerosol components are: water-insoluble, water soluble, soot, sea-salt accumulation mode, sea-salt coarse mode, mineral nucleation mode, mineral accumulation mode, mineral coarse mode, mineral transport mode, and sulphate (nucleation, accumulation, coarse, and transport modes deal with size classes for sea-salt and mineral aerosols). For each aerosol component, the optical properties, i.e. the extinction, scattering, and absorption coefficients, single scattering albedo, asymmetry factor, phase function, and optical depth, are calculated with Mie theory at 61 wavelengths from 0.25 to $40 \mu \mathrm{m}$, and for 8 values of relative humidity $(0,50,70,80,90,95,98$, and $99 \%)$, while visibility and Angstrom coefficient are also provided. The columnar aerosol properties are calculated on the basis of exponential aerosol height profiles (Jaenicke, 1993; Koepke et al., 1997; Hess et al., 1998). Global distributions of GADS aerosol properties are given as climatologically averaged values both for the periods December through February (Northern Hemisphere winter) and June through August (Northern Hemisphere summer) seasons on a $5^{\circ}$ by $5^{\circ}$ latitudelongitude resolution. However, to match the spatial resolution of the climatological parameters, especially that of relative humidity to which the aerosol properties are sensitive, the original GADS aerosol optical properties were up-scaled to $1^{\circ} \times 1^{\circ}$ latitude-longitude resolution, as explained in the next paragraph.

The aerosol properties originally taken from GADS for 8 values of relative humidity (see previous paragraph) were 

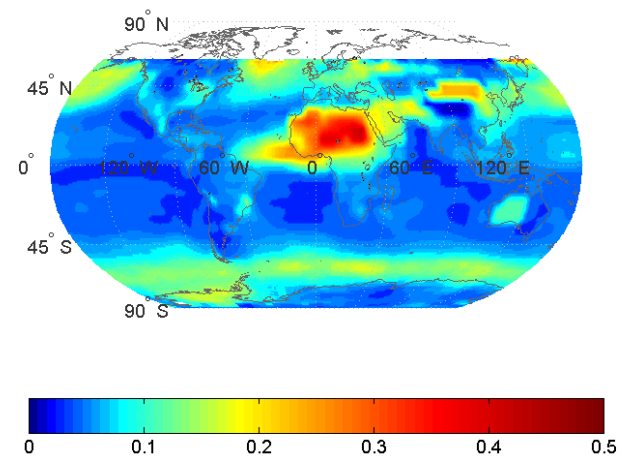

(i-a)
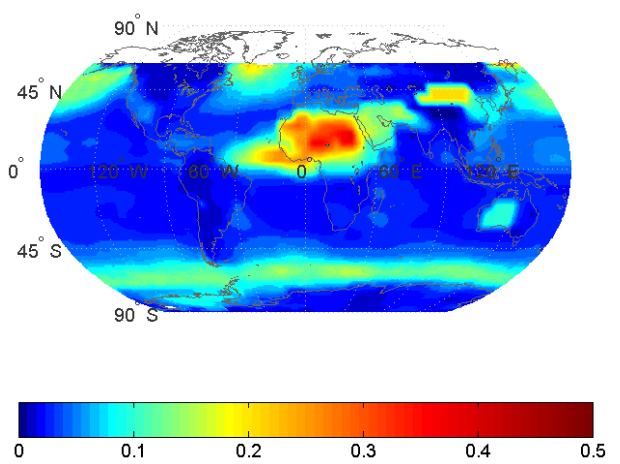

(ii-a)
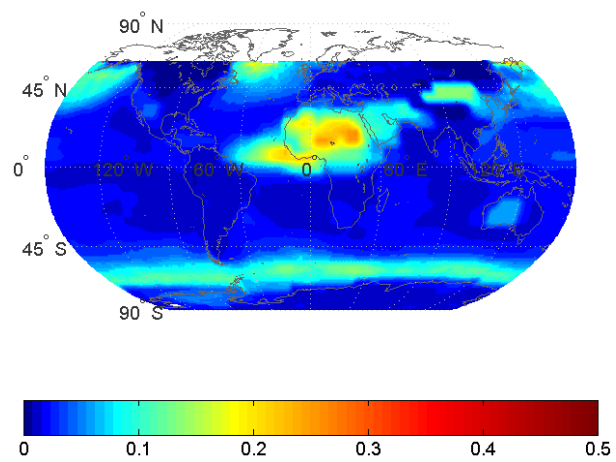
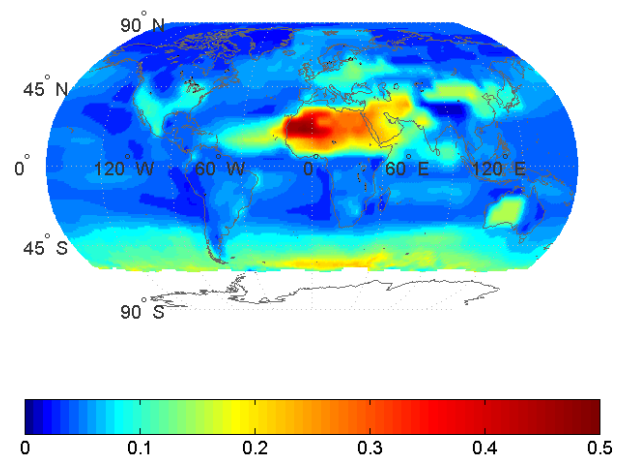

(i-b)
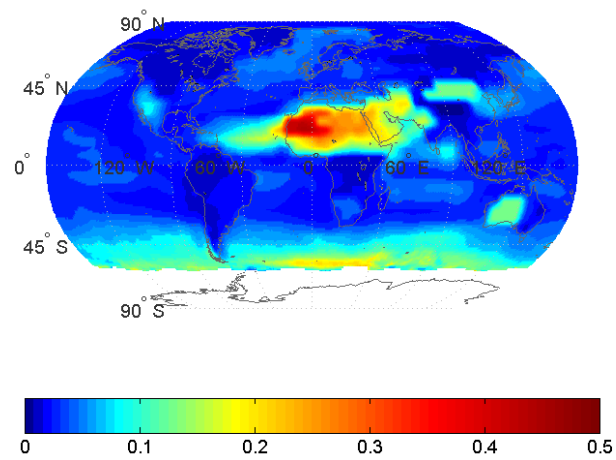

(ii-b)
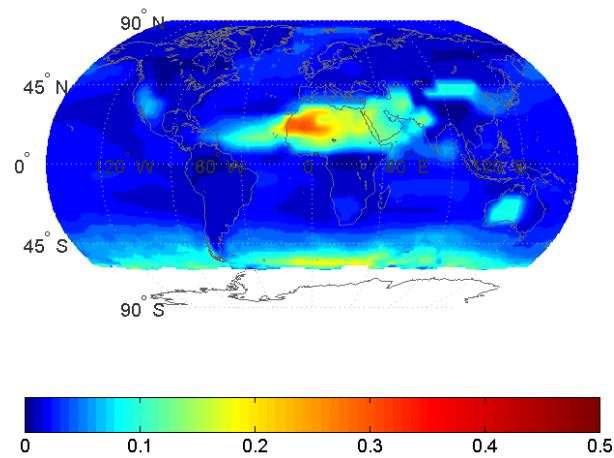

(iii-b)

Fig. 1. Global distribution of aerosol optical thickness at (i) $0.9 \mu \mathrm{m}$, (ii) $1.75 \mu \mathrm{m}$, and (iii) $3.5 \mu \mathrm{m}$, for (a) January and (b) July.

re-computed for actual relative humidity values for the aerosol layer, in order to compute realistically the aerosol DREs. These properties originally taken from GADS, were re-computed for actual relative humidity values for the aerosol layer, in order to compute realistically the aerosol radiative DREs. This was done by using atmospheric profiles of temperature and specific humidity, taken from the GEOS Reanalysis Project for the years 1984-1995, Subsequently, the effective mean (computed by convoluting the relative humidity with altitude and the aerosol particle concentration decrease with height) relative humidity value was estimated, corresponding to the tropospheric aerosol layer extent.

The GADS aerosol properties are given at 29 wavelengths within 0.85 to $10 \mu \mathrm{m}$. These are: $0.9,1.0,1.25,1.5,1.75$, $2.0,2.5,3.0,3.2,3.39,3.5,3.75,4.0,4.5,5.0,5.5,6.0,6.2$, $6.5,7.2,7.9,8.2,8.5,8.7,9.0,9.2,9.5,9.8$ and $10.0 \mu \mathrm{m}$. 

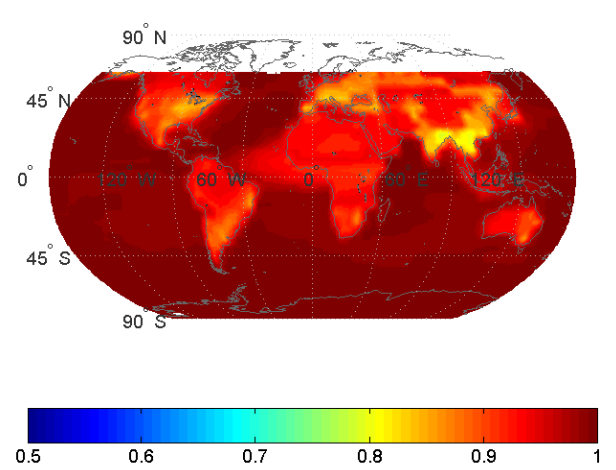

(i-a)
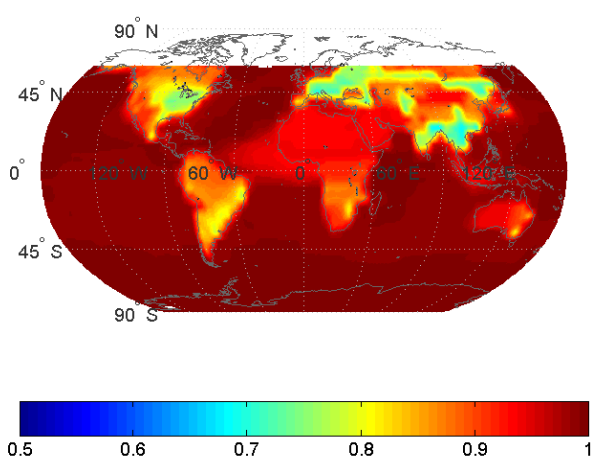

(ii-a)
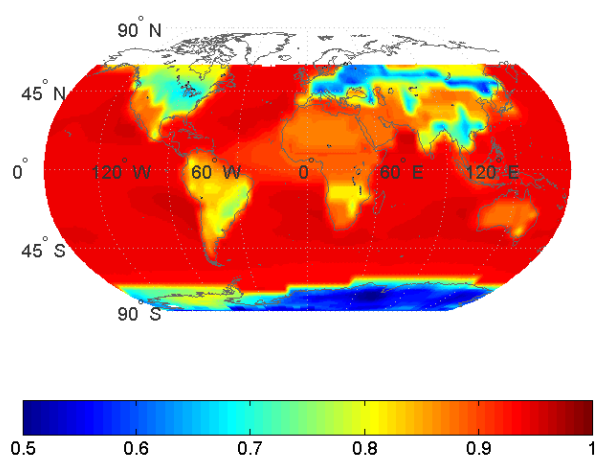
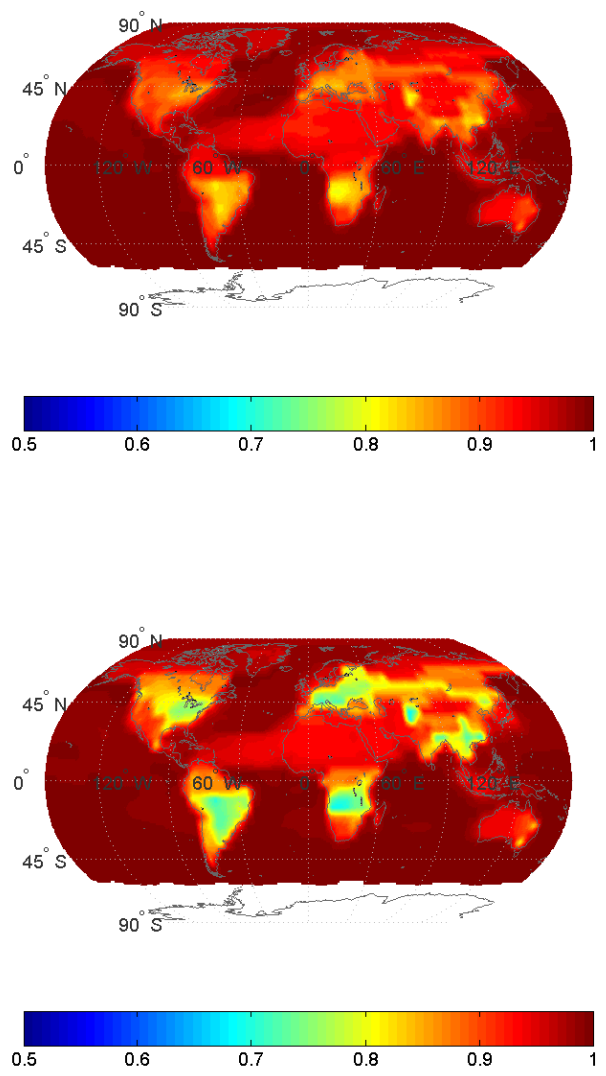

(ii-b)

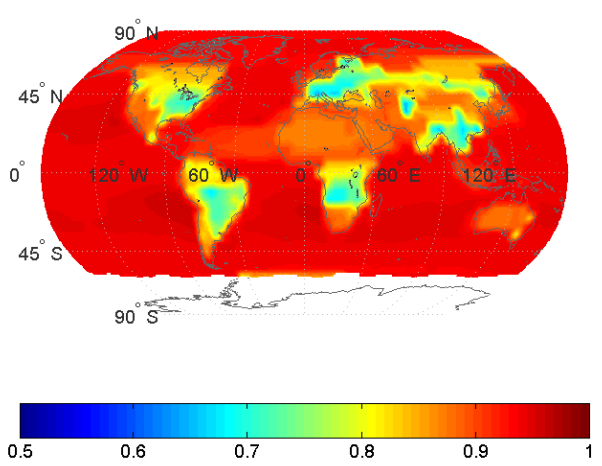

(iii-a) (iii-b)

Fig. 2. Global distribution of aerosol single scattering albedo at (i) $0.9 \mu \mathrm{m}$, (ii) $1.75 \mu \mathrm{m}$, and (iii) $3.5 \mu \mathrm{m}$, for (a) January and (b) July.

The spectral model computations are performed for specific wavelengths and spectral intervals in the near-IR. Thus, the model required AOT, $\omega_{\text {aer }}$, and $g_{\text {aer }}$ for these wavelengths and intervals were obtained through interpolation. Finally, the near-IR radiative fluxes at TOA, within the atmosphere, and at the Earth's surface, were computed for each wavelength and spectral interval, with and without aerosols, which were then summed to yield the near-IR radiative fluxes, and from their difference the radiative effects (Eq. 11).
As examples, the global distribution of GADS-derived aerosol optical properties are given in Figs. 1, 2 and 3, for the wavelengths $0.9 \mu \mathrm{m}, 1.75 \mu \mathrm{m}$ and $3.5 \mu \mathrm{m}$, respectively, computed for the ambient aerosol layer humidity, for Northern Hemisphere winter (January) and summer (July) conditions. Blanks in Figs. 1 to 3 correspond to areas with missing data. It can be seen that AOT values (Fig. 1) decrease with increasing wavelength, especially over highly populated and industrialized areas (e.g. Europe, North and South America, 

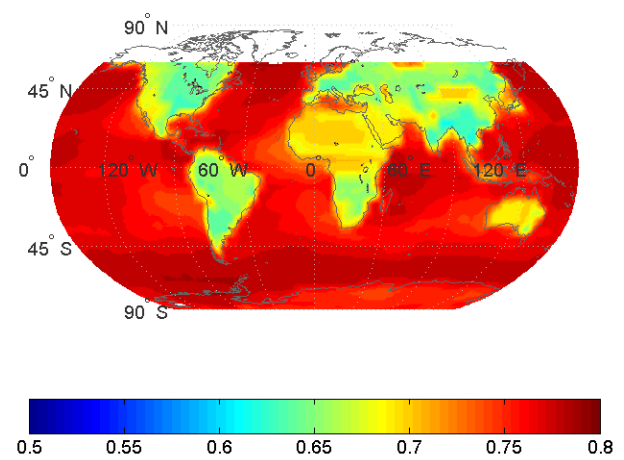

(i-a)
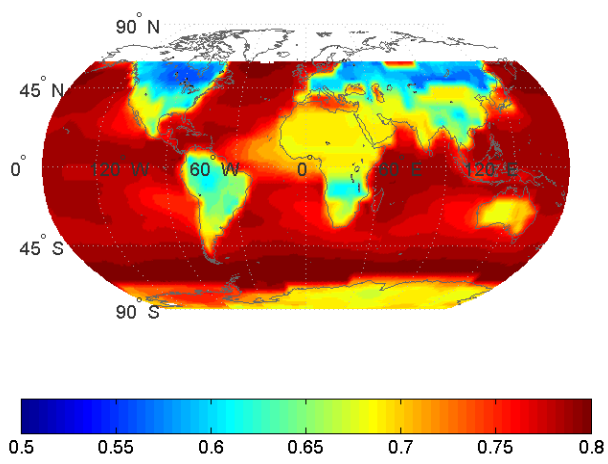

(ii-a)
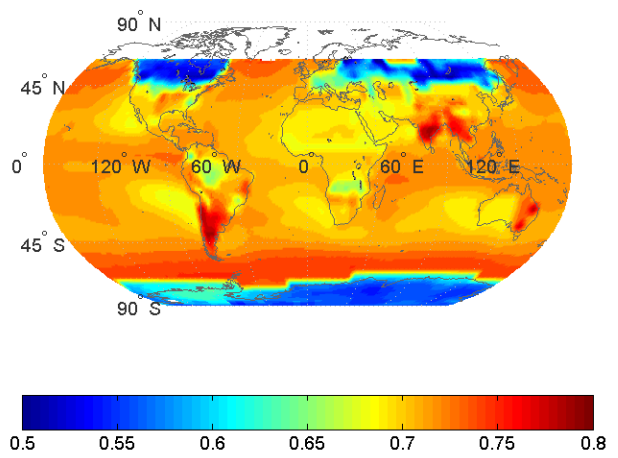
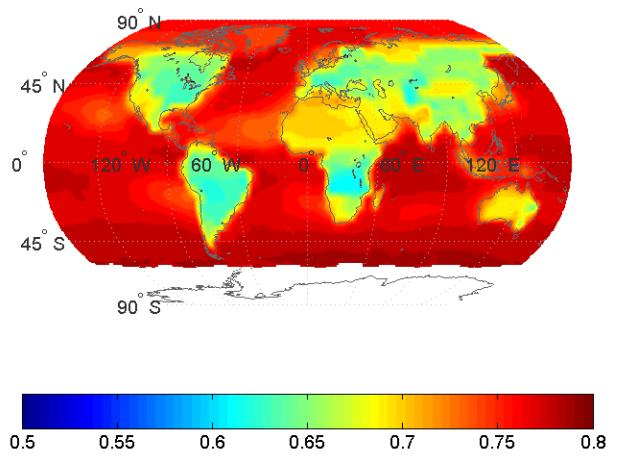

(i-b)
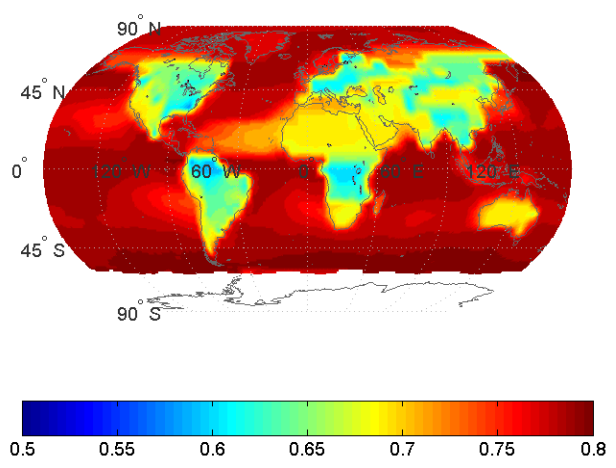

(ii-b)
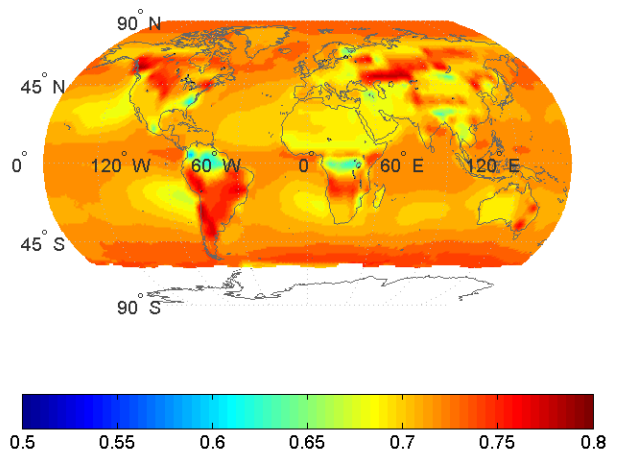

(iii-b)

Fig. 3. Global distribution of aerosol asymmetry parameter at (i) $0.9 \mu \mathrm{m}$, (ii) $1.75 \mu \mathrm{m}$, and (iii) $3.5 \mu \mathrm{m}$, for (a) January and (b) July.

South and South-East Asia) with fine particles. In contrast, areas with coarse particles such as North Africa, Arabian and Gobi deserts or the windy zone (around $60^{\circ} \mathrm{S}$ ) of the Southern Hemisphere, maintain relatively high AOT values for near-IR wavelengths, because of the large sizes of dust and sea-salt particles. In those areas, AOT values are up to 0.47 at $0.9 \mu \mathrm{m}$ and 0.32 at $3.5 \mu \mathrm{m}$, whereas they are smaller than 0.1 at all wavelengths for the rest of globe. The single scattering albedo values (Fig. 2) range from 0.5 to 1 in the near-IR range. Large values of $\omega_{\text {aer }}$ are found over oceanic areas with sulphate and sea-salt particles, decreasing to about 0.65 over continental areas with water soluble, water insoluble and soot components (e.g. Europe, North and South America, South and South-East Asia). According to GADS, the water insoluble part of aerosol particles are a mixture of dust (soil particles) and organic material, whereas the water 
soluble part consists of various kinds of sulphates, nitrates, and other, also organic, water soluble substances. The single scattering albedo for water soluble substances indicates relatively high absorption properties, while the assumed refractive index values indicate a slightly absorbing water soluble component. As for the GADS soot component, it is used to represent absorbing black carbon particles characterized by its high imaginary part of the refractive index. In contrast to water soluble and insoluble as well as soot components, sea-salt and sulphate components are highly scattering as indicated by an associated extremely low imaginary part of the refractive indices (see Koepke et al., 1997). It is interesting that over desert areas, but also over oceanic regions characterized by dust transport (such as tropical Atlantic, and western Pacific off the Asian coast), the $\omega_{\text {aer }}$ values are larger in the near-IR than in the UV-visible wavelengths. For example, over North Africa in July, $\omega_{\text {aer }}$ is equal to 0.93 at $0.9 \mu \mathrm{m}$ and 0.87 at $3.5 \mu \mathrm{m}$ (Fig. 2), against 0.65 at $0.25 \mu \mathrm{m}$ (see Fig. 2 of Hatzianastassiou et al., 2004a). This is explained by the decreasing imaginary refractive index of mineral components from the UV through to about $1.0 \mu \mathrm{m}$, before increasing again at larger wavelengths. Note also the drastic drop of $\omega_{\text {aer }}$ over Antarctica in January, due to the composition of Antarctic aerosols from sulphate solution (Koepke et al., 1997). The aerosol asymmetry parameter (Fig. 3) has values in the near-IR varying between 0.5 and 0.81 , i.e. lower than corresponding values in the UV-visible (0.6-0.85, Hatzianastassiou et al., 2004a). More forward scattering from aerosols is indicated by larger oceanic than continental $g_{\text {aer }}$ values. In general, $g_{\text {aer }}$ decreases with increasing wavelength. However, over areas dominated by a large mass concentration of mineral aerosols (e.g. Sahara, Gobi, western Australia) $g_{\text {aer }}$ remains unchanged with increased wavelength, whilst over regions with strong water insoluble aerosol components (e.g. South America, eastern USA, Europe, South and SouthEast Asia in January), there is an increase in $g_{\text {aer }}$ from 0.9 to $3.5 \mu \mathrm{m}$.

\subsection{Other data}

The molecules considered in this study relevant to the nearIR range of wavelengths were: $\mathrm{H}_{2} \mathrm{O}, \mathrm{CO}_{2}$ and $\mathrm{CH}_{4}$. Their absorption was treated as explained in the previous section (2). The Rayleigh scattering due to atmospheric molecules, which is important only for wavelengths up to $1 \mu \mathrm{m}$, is considered in the model in the way described by Vardavas and Carver (1984) and Hatzianastassiou et al. (2004a). The total atmospheric amounts for atmospheric molecules were partially distributed into each atmospheric layer according to its physical thickness as part of the total atmospheric column height.

The water vapour and temperature data were based on the GEOS-1 reanalysis product (6-hourly), averaged to a daily temporal resolution. Atmospheric temperature and humidity profiles for the years 1984 through to 1995 were used to com- pute the mean relative humidity of the aerosol layer. Cloud data on a $1^{\circ} \times 1^{\circ}$ resolution were taken from the NASALangley data set based on GEWEX ISCCP DX cloud climatologies. The mean daily $1^{\circ} \times 1^{\circ}$ NASA-Langley cloud data were compiled by processing the 3-hourly ISCCP-DX pixel-level data, which contain radiance and cloud retrieval information from geosynchronous and polar orbiting satellites sampled to a nominal resolution of $30 \mathrm{~km}$. All $30 \mathrm{~km}$ DX pixels within a grid cell are averaged analogously to the methods of ISCCP (e.g. Rossow et al., 1996) to produce gridded radiance and cloud products. The NASA Langley $1^{\circ} \times 1^{\circ}$ cloud data include: cloud amount, cloud-top pressure, cloudtop temperature, liquid water path, and optical depth for total clouds. They also provide cloud amount and cloud-top temperature for low-, mid-, and high-level clouds, as well as cloud amount, cloud-top temperature, cloud optical depth, and cloud albedo separately for ice and liquid water phase clouds. We used in our study cloud amount, cloud optical depth and cloud-top pressure.

The surface reflection is computed as in Vardavas and Koutoulaki (1995), Hatzianastassiou et al. (2004a) and Hatzianastassiou et al. (2005), by using surface-type cover fractions on a mean daily and 1-degree geographical cell resolution for the years 1984-1995. Ice/snow cover data were taken from ISCCP, while surface type classification maps were obtained from other high resolution data sets (Stackhouse et al., 2002).

A complete topography scheme is included in the model, which uses the NASA DAO GEOS- 1 surface pressure, gridded on $1^{\circ} \times 1^{\circ}$ cells. Consideration of topography is important for regions well above sea-level, for the correct computation of the mean aerosol layer humidity, but also for the correct computation of total atmospheric amount of each gas for the actual extent of the atmospheric column for a given geographical cell on the globe.

\section{Model computations of near-infared aerosol radiative effects}

The spectral model computations were performed using the spectral (see Sect. 3.1) GADS aerosol properties. The nearIR radiative fluxes at TOA, within the atmosphere, and at the Earth's surface, were computed for each wavelength and spectral interval, with and without aerosols, which were then summed to yield the near-IR radiative fluxes, and from their difference the radiative effects (Eq. 11). The computed total near-IR mean monthly (winter and summer) aerosol DREs for each cell $\left(1^{\circ}\right.$ longitude-latitude) are given in terms of outgoing radiation at TOA $\left(\Delta \mathrm{F}_{\mathrm{TOA}}\right)$, atmospheric absorption $\left(\Delta \mathrm{F}_{\mathrm{atmab}}\right)$ and net downward or absorbed radiation at the surface $\left(\Delta \mathrm{F}_{\text {surfnet }}\right)$ in $\mathrm{W} \mathrm{m}^{-2}$. 
4.1 Aerosol direct radiative effect at the top of atmosphere $\left(\Delta \mathrm{F}_{\mathrm{TOA}}\right)$

The change of outgoing near-IR radiation at TOA due to aerosols (aerosol direct radiative effect $\Delta \mathrm{F}_{\mathrm{TOA}}$ ) under allsky conditions is given in Fig. 4. According to Eq. (11), positive values indicate decreased outgoing near-IR radiation, i.e. near-IR radiative warming of the Earth-atmosphere system, while negative values indicate planetary cooling. Blanks in Fig. 4 correspond to areas with missing data. In general, aerosols increase, through reflection, the outgoing nearIR radiation at TOA (negative values of $\Delta \mathrm{F}_{\mathrm{TOA}}$ ), by up to $6 \mathrm{~W} \mathrm{~m}^{-2}$ on a mean monthly basis, producing thus planetary cooling. Over most of the globe, the change in nearIR radiation is smaller than $1-2 \mathrm{~W} \mathrm{~m}^{-2}$. The large values of $\Delta \mathrm{F}_{\mathrm{TOA}}$ occur over continental desert areas (e.g. Sahara, Arabian peninsula, Gobi, Australia), over oceanic areas with strong dust transport above (e.g. tropical Atlantic Ocean) and over remote oceanic areas with intense production of seaspray (storm-track zone of the Southern Hemispere). In particular, as far as dust is concerned, studies (e.g. Sokolik and Toon, 1999; Kaufman et al., 2001) have shown that the treatment of particle aggregation is crucial for the dust radiative effect, since this can be reversed from positive to negative and vice-versa. In GADS, mineral aerosol or desert dust produced in arid regions consists of quartz and clay minerals (e.g. hematite). These particles are described by four components having the same refractive index but different sizes (see Koepke et al., 1997). The refractive index is based on a compilation of data as discussed by Carlson and Benjamin (1980) and Sokolik et al. (1993). In spite of the general near-IR planetary cooling, aerosols can produce a warming of the Earth-atmosphere system by decreasing the outgoing near-IR radiation at TOA, by up to $1 \mathrm{~W} \mathrm{~m}^{-2}$. This occurs over Greenland in July and over limited areas (e.g. Sahara) with large surface albedo and significant loads of absorbing aerosols, as also reported in previous studies (e.g. Ming et al., 2005). In general, under all-sky conditions, the effect of aerosols on the outgoing near-IR radiation at TOA is smaller than their effect on the UV-visible wavelengths (values ranging from -9 to $8.5 \mathrm{~W} \mathrm{~m}^{-2}$, not shown here). The magnitude of $\Delta \mathrm{F}_{\mathrm{TOA}}$ for a specific place on the globe is not only determined by aerosol optical properties such as AOT, $\omega_{\text {aer }}$ and $g_{\text {aer }}$, but also by cloud cover and surface albedo, apart from the incoming solar flux. The role of cloud cover is indicated by large values appearing in regions with small cloudiness, e.g. sub-Sahel, Gobi and Australian deserts in January. In July, large negative values (up to minus $5-6 \mathrm{~W} \mathrm{~m}^{-2}$ ) exist over limited maritime areas such as the southern part of the eastern Mediterranean basin and the Red Sea, and secondarily over continental areas such as Australia. Negative values (up to $-1 \mathrm{~W} \mathrm{~m}^{-2}$ ) appear over Sahelian and Sahara regions with large AOT, small cloudiness and large (0.3-0.4) surface albedo. The role of surface albedo is very important in determining the sign of $\Delta \mathrm{F}_{\mathrm{TOA}}$. Thus, highly reflect- ing surfaces under significantly absorbing aerosols lead to an aerosol warming effect at TOA $\left(\Delta \mathrm{F}_{\mathrm{TOA}}>0\right.$ in Fig. 4$)$ due to particle absorption that is increased through multiple reflections between the surface and the aerosols above. This occurs especially in July and much less in January. It is interesting to note that over continental areas with smaller surface albedo $(0.2$ to 0.3$)$ adjacent to areas with $\Delta \mathrm{F}_{\mathrm{TOA}}>0$, or over maritime areas with low surface albedo $(<0.1)$, the values of $\Delta \mathrm{F}_{\mathrm{TOA}}$ change to negative, as in the case of tropical Atlantic with dust transport, where $\Delta \mathrm{F}_{\mathrm{TOA}}$ equals -1 to $-2 \mathrm{~W} \mathrm{~m}^{-2}$. The role of surface albedo in changing the sign of $\Delta \mathrm{F}_{\mathrm{TOA}}$ was verified through sensitivity studies performed with our model. Another case of positive near-IR DRE at TOA is in Greenland, where $\Delta \mathrm{F}_{\mathrm{TOA}} \cong 0.2 \mathrm{~W} \mathrm{~m}^{-2}$ in July; positive DRE appears there despite the small aerosol load $(\mathrm{AOT}<0.1)$ because of large surface albedo. Note also the relatively large values of $\Delta \mathrm{F}_{\mathrm{TOA}}\left(\cong-1 \mathrm{~W} \mathrm{~m}^{-2}\right)$ along the storm-track zone of the Southern Hemisphere in January, due to the aerosol optical thickness values of $\cong 0.1-0.2$ and relatively low surface albedo $(<0.15-0.2)$. In contrast, $\Delta \mathrm{F}_{\mathrm{TOA}}$ is smaller in July despite the significant AOT values (similar to those of January), because of the increased surface albedo (0.3-0.35) due to increased Fresnel reflection (and solar zenith angle, see Hatzianastassiou et al., 2004a) under cloud-free conditions and the small amount of incoming solar radiation at that season.

\subsection{Aerosol direct radiative effect in the atmosphere $\left(\Delta \mathrm{F}_{\mathrm{atmab}}\right)$}

Aerosols are found to increase the near-IR atmospheric absorption (Fig. 5), by as much as $7 \mathrm{~W} \mathrm{~m}^{-2}$, over areas characterized by significant amounts of absorbing aerosols (such as mineral-dust or soot), especially over highly reflecting surfaces (surface albedo $>0.3$ ). Aerosol DRE values up to 2$3 \mathrm{~W} \mathrm{~m}^{-2}$ are also found over Europe, USA, South America, South Africa, South and South-East Asia and Australia. The large values of $\Delta \mathrm{F}_{\mathrm{atmab}}$ are either associated with large mass concentrations of absorbing mineral aerosol components or with significant (but smaller) concentrations of strongly absorbing soot or water soluble and insoluble components. The near-IR aerosol DREs are found to be smaller, by factor of about 0.3 , compared to the corresponding UV-visible aerosol DREs, but need to be accounted for in climate studies. In January, the large values of $\Delta \mathrm{F}_{\mathrm{atmab}}$ in sub-Sahel $\left(5^{\circ}-10^{\circ} \mathrm{N}\right)$ and across the tropical Atlantic are attributed to the longrange transport of desert dust in higher atmospheric levels (up to $4.5 \mathrm{~km}$, Formenti et al., 2003) by the "harmattan" trade winds during the dry season. The transport of mineral dust across the Atlantic ocean, as indicated by large values of $\Delta \mathrm{F}_{\mathrm{atmab}}$, is shifted northwards in July due to the changed atmospheric circulation (Azores anticyclone and thermal low of Pakistan). Note that slightly negative $\Delta \mathrm{F}_{\mathrm{atmab}}$ values are found over limited areas, such as the Antarctica, especially its western part (along the coast of Marie Byrd Land), and 

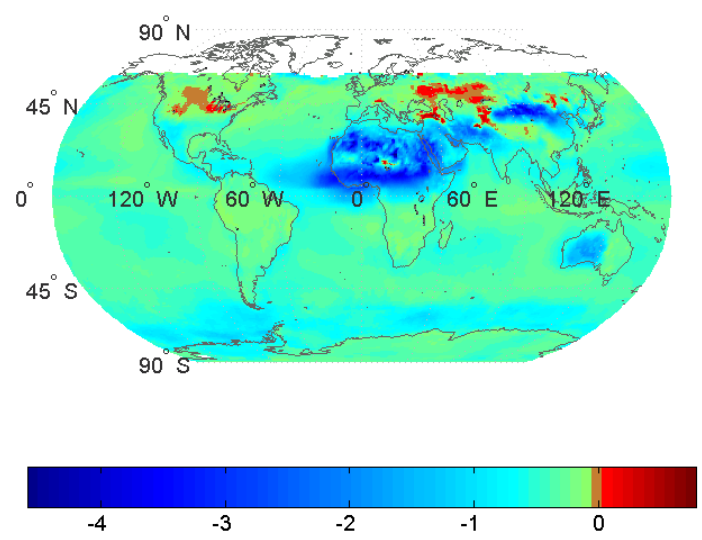

(a)

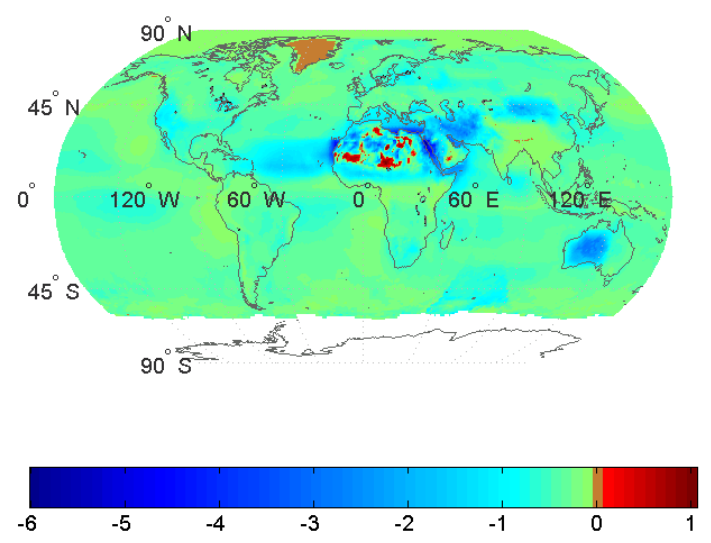

(b)

Fig. 4. Global distribution of the aerosol direct radiative effect (DRE) on the outgoing near-IR radiation at top-of-atmosphere (aerosol DRE $\Delta \mathrm{F}_{\mathrm{TOA}}, \mathrm{W} \mathrm{m}^{-2}$ ), for (a) January and (b) July.

the northernmost parts of the Atlantic and Pacific oceans in January, as well as along the windy oceanic zone of the Southern Hemisphere in July, i.e. over areas with significant loads of highly scattering aerosols. In these cases, the atmospheric layer including scattering aerosols (water-soluble or sea-salt) is high enough and absorbs less near-IR radiation than it would do without these particles. Such behavior does not occur in the UV-visible wavelengths (Hatzianastassiou et al., 2004a).

\subsection{Aerosol direct radiative effect at surface $\left(\Delta \mathrm{F}_{\text {surfnet }}\right)$}

Our model results (Fig. 6) indicate that aerosols decrease regionally the surface downward (not shown here since the results are very similar to those for the absorbed component) and the absorbed near-IR radiation at the Earth's surface by up to 12 and $10 \mathrm{~W} \mathrm{~m}^{-2}$, respectively, producing thus an important surface radiative cooling. The largest decreases in

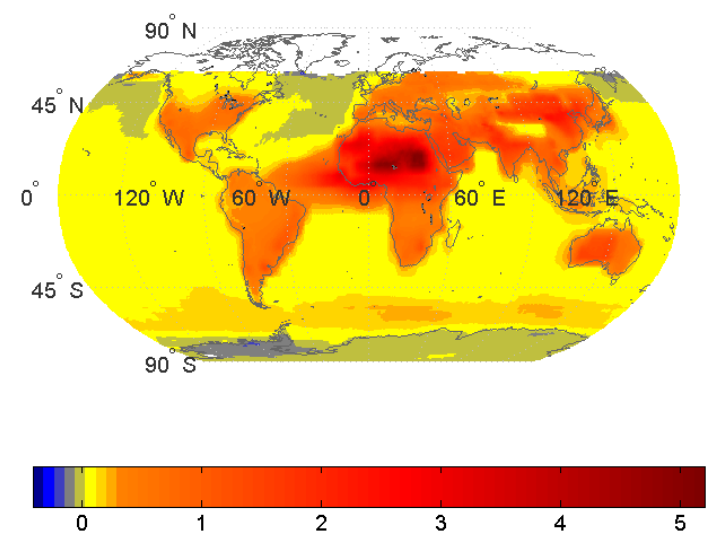

(a)

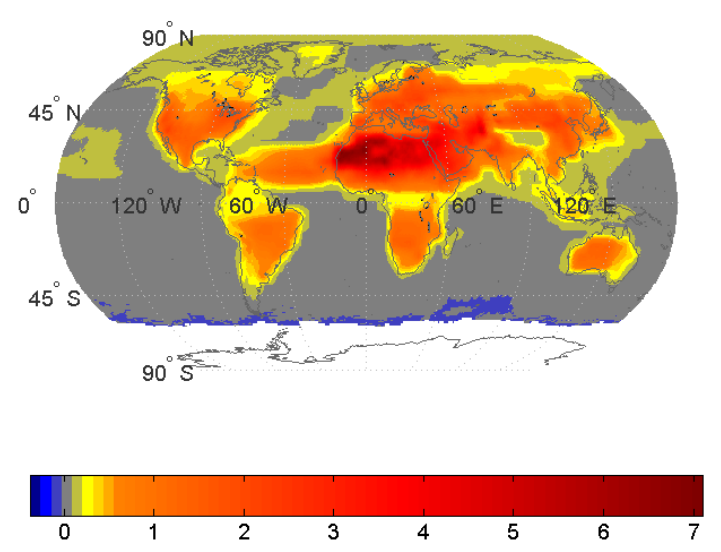

(b)

Fig. 5. Global distribution of the aerosol direct radiative effect (DRE) on the atmospheric absorption of near-IR radiation (aerosol DRE $\Delta \mathrm{F}_{\text {atmab }}, \mathrm{W} \mathrm{m}^{-2}$ ), for (a) January and (b) July.

surface near-IR radiation are found over areas with significant aerosol amounts (AOT). Thus, over desert areas during summer the surface absorption of near-IR radiation is decreased by up to $10 \mathrm{~W} \mathrm{~m}^{-2}$ due to the scattering and absorption of aerosols. In the rest of the continental areas, aerosols produce a radiative near-IR cooling of the surface up to $2-3 \mathrm{~W} \mathrm{~m}^{-2}$. According to our model computations, the aerosol effect on near-IR radiation at the surface is larger, by up to 3-4 times, than at TOA at geographical cell level, i.e. the ratio $\Delta \mathrm{F}_{\text {surfnet }} / \Delta \mathrm{F}_{\mathrm{TOA}}$ takes slightly larger values in the near-IR than in the UV-visible range for which the ratio is about 3 (Hatzianastassiou et al., 2004a). Lelieveld et al. (2002) have reported a factor of 2.7 from aerosol radiative forcing computations based on measurements of the Mediterranean Intensive Oxidation Study, performed in summer 2001 in Crete (Greece). In general, the near-IR aerosol DRE values at the surface are smaller in magnitude than the corresponding UV-visible by $2-3$ times. However, the ratio 
of UV-visible/near-IR aerosol DRE at surface is even larger, i.e. by up to about 5 times, over regions with fine particles, such as the industrialized/urban regions of the North Hemisphere (Europe, USA, South and South-East Asia). This is further discussed in Sect. 5.

4.4 Global and hemispherical averages of aerosol direct radiative effects

The global and hemispherical averages of near-IR aerosol DREs were estimated, by including surface area weighting in the computations, and the results are given in Table 1 . The largest effect of aerosols on near-IR radiation is found at the surface, where the downward and absorbed fluxes are decreased by about 1.0 and $0.85 \mathrm{~W} \mathrm{~m}^{-2}$, respectively, on global scale. In the atmosphere, the presence of aerosol particles increases the absorption of near-IR radiation by about $0.4 \mathrm{~W} \mathrm{~m}^{-2}$, whereas the globally averaged reflected near-IR flux to space is found to increase by about $0.5 \mathrm{~W} \mathrm{~m}^{-2}$. Overall, the presence of aerosols results in atmospheric warming due to absorption of near-IR solar radiation, a stronger surface near-IR radiative cooling, and a near-IR cooling of the Earth-atmosphere system. These near-IR DREs are in qualitative agreement with the corresponding effects at UV-visible wavelengths (Hatzianastassiou et al., 2004a) but smaller in magnitude. However, they are still very important for climate since their magnitude is of the order of $1 \mathrm{~W} \mathrm{~m}^{-2}$.

The near-IR DRE values are generally larger in the more polluted Northern Hemisphere than in the Southern, by factors ranging from 1.2 to 6 depending on the DRE component and month. The largest inter-hemispherical differences occur for the aerosol effect on atmospheric absorption of near-IR flux, with the ratio $\Delta \mathrm{F}_{\text {atmab }}$ (North) $/ \Delta \mathrm{F}_{\text {atmab }}$ (South) equal to 3 and 6 in January and July, respectively. In general, there are small differences between the magnitude of aerosol DRE values in January and July, as also reported by Koepke et al. (1997). Nevertheless, large seasonal differences (between January and July) are found with respect to the interhemispherical contrast in DRE magnitude. For example, the much larger ratio, $\Delta \mathrm{F}_{\text {atmab }}$ (North) $/ \Delta \mathrm{F}_{\text {atmab }}$ (South), in July (6.1) than in January (3.1) arises from the seasonal cycles of mineral dust and biomass burning in the two hemispheres.

\section{Aerosol radiative effect on atmospheric thermal dy- namics}

As shown in Sects. 4.2 and 4.3, aerosols cool the Earth's surface by scattering to space and through atmospheric absorption. Therefore, the presence of aerosols has a significant effect on the thermal dynamics of the Earth-atmosphere system. By cooling the surface and warming the atmosphere, aerosols act to produce more stable atmospheric conditions by decreasing convective activity. They also reduce evaporation from the surface, and so can have a significant effect on
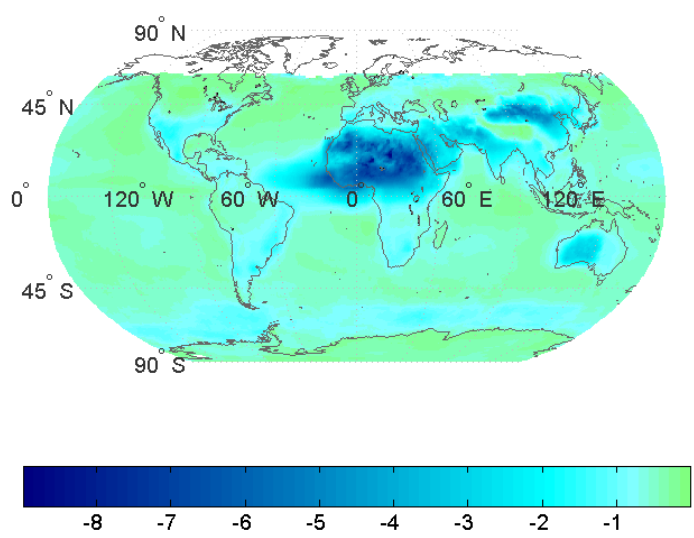

(a)

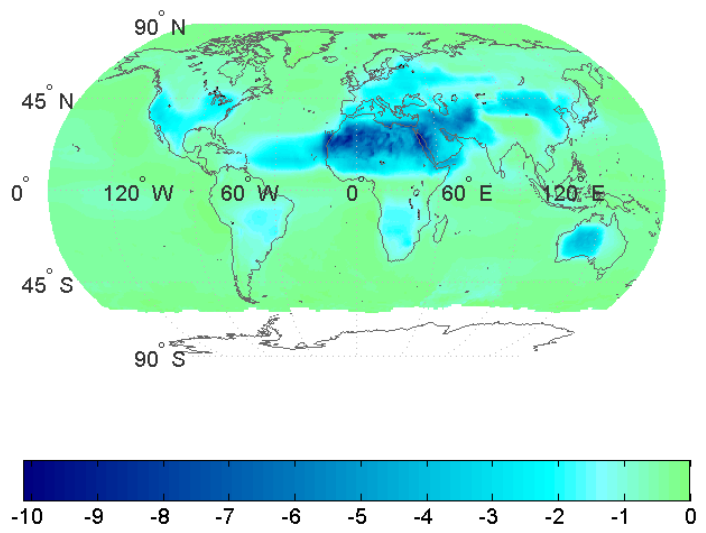

(b)

Fig. 6. Global distribution of the aerosol direct radiative effect (DRE) on the absorbed near-IR radiation by the Earth's surface (aerosol DRE $\Delta \mathrm{F}_{\text {surfnet }}, \mathrm{W} \mathrm{m}^{-2}$ ), for (a) January and (b) July.

the hydrological cycle by suppressing cloud formation (especially the convective) and associated precipitation. This aerosol redistribution of near-IR radiative energy between the Earth's surface and the atmosphere, was also found for the UV-visible (Hatzianastassiou et al., 2004a). This highlights the role of modifying atmospheric particulate matter (amount and composition) on climate, especially in climatically sensitive regions such as the desertification threatened Mediterranean basin. We quantify the magnitude of this aerosol effect on thermal dynamics (AETD) by the difference

$\mathrm{AETD}=\Delta F_{\text {atmab }}-\Delta F_{\text {surfnet }}$

given in Fig. 7.

The magnitude of AETD can be up to 13 and $16 \mathrm{~W} \mathrm{~m}^{-2}$ for January and July, respectively, with a magnitude up to 5 and $2 \mathrm{~W} \mathrm{~m}^{-2}$ over most continental and oceanic areas, respectively. It is interesting to note that the largest effect of aerosols on thermal dynamics occurs over deserts and nearby 
Table 1. Mean global and hemispherical $(\mathrm{NH}, \mathrm{SH})$ all-sky near-IR aerosol direct radiative effect (DRE, denoted as $\Delta \mathrm{F}$ in $\mathrm{W} \mathrm{m}^{-2}$ ) for January and July. The DRE components are given in terms of: outgoing radiation at TOA $\left(\Delta \mathrm{F}_{\mathrm{TOA}}\right)$, radiation absorbed in the atmosphere $\left(\Delta \mathrm{F}_{\text {atmab }}\right)$, downward radiation at surface $\left(\Delta \mathrm{F}_{\text {surf }}\right)$, and net downward (absorbed) radiation at surface $\left(\Delta \mathrm{F}_{\text {surfnet }}\right)$.

\begin{tabular}{llllll}
\hline \multirow{4}{*}{ January } & $\Delta \mathrm{F}_{\mathrm{TOA}}$ & $\Delta \mathrm{F}_{\text {atmab }}$ & $\Delta \mathrm{F}_{\text {surf }}$ & $\Delta \mathrm{F}_{\text {surfnet }}$ \\
\hline \multirow{4}{*}{ July } & Globe & -0.5 & 0.36 & -1.04 & -0.85 \\
& North Hemisphere & -0.62 & 0.49 & -1.4 & -1.12 \\
& South Hemisphere & -0.43 & 0.16 & -0.71 & -0.59 \\
& Globe & -0.47 & 0.39 & -1.02 & -0.86 \\
& North Hemisphere & -0.51 & 0.67 & -1.45 & -1.18 \\
& South Hemisphere & -0.43 & 0.11 & -0.59 & -0.54 \\
\hline
\end{tabular}
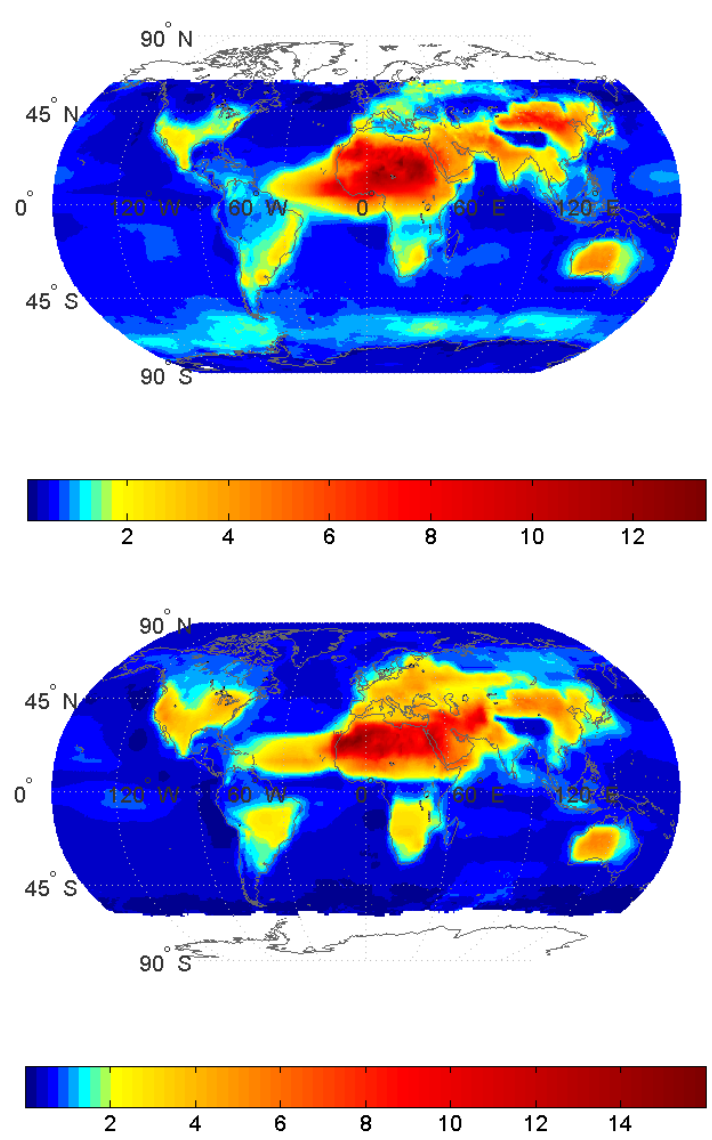

Fig. 7. Aerosol near-IR radiative effect on atmospheric thermal dynamics $\left(\Delta \mathrm{F}_{\text {atmab }}-\Delta \mathrm{F}_{\text {surfnet }}\right.$, in $\left.\mathrm{W} \mathrm{m}^{-2}\right)$, for (a) January and (b) July.

desertification threatened regions. Of course, this aerosol radiative effect is further amplified when the corresponding effect at UV-visible wavelengths is also included (not shown here).

\section{Contribution of near-infared to total shortwave aerosol direct radiative effect}

In order to quantify the relative contribution of near-IR to the total SW aerosol direct radiative effect, the percentage of total DRE due to the near-IR was computed for the three components (at TOA, in the atmosphere and at surface), for January and July, and the results are given in Fig. 8. As for $\Delta \mathrm{F}_{\mathrm{TOA}}$, over most regions, the near-IR DRE contribution to the total SW DRE is 25-30\%. Nevertheless, over extended desert areas (e.g. Sahara, Arabian, Australian, Gobi) the contribution rises to about $50 \%$, and over limited areas it even exceeds the magnitude of the total SW DRE (values up to $200 \%$ or even larger). At first sight this may seem strange but it can be explained by the different sign of aerosol DRE at TOA $\left(\Delta \mathrm{F}_{\mathrm{TOA}}\right)$ for the near-IR and the UV-visible. The sum of the UV-visible and near-IR components is smaller than the components themselves. This also explains the existence of negative values in Fig. 8, over limited regions. The changing sign of $\Delta \mathrm{F}_{\mathrm{TOA}}$ between the UV-visible and near-IR wavelengths is attributed to: (i) the decrease in AOT towards the near-IR; (ii) the decrease in surface albedo over snow (e.g. Roesch et al., 2002), sea-ice (e.g. Allison, 1993) or land-ice (e.g. Hansen et al., 1983; Roesch et al., 2002) with increasing wavelength; (iii) the increase of $\omega_{\text {aer }}$, e.g. from values of about 0.65 at $0.25 \mu \mathrm{m}$ to 0.88 at $3.5 \mu \mathrm{m}$ over the Sahara in July; and (iv) the decrease of $g_{a e r}$, e.g. from values of about 0.82 at $0.25 \mu \mathrm{m}$ to 0.67 at $3.5 \mu \mathrm{m}$ over the Sahara in July. The combination of all the above results in a near-IR $\Delta F_{T O A}$ with opposite sign to that of the UV-visible $\Delta \mathrm{F}_{\mathrm{TOA}}$ over areas such as the Sahara and the Arctic in July. Consequently, careful consideration of the spectral dependence of aerosol DRE at TOA is required to avoid erroneous conclusions regarding the role of aerosols for the Earth's climate (planetary warming instead of cooling and vice versa).

The contribution of near-IR to total SW DRE in the atmosphere $\left(\Delta \mathrm{F}_{\mathrm{atmab}}\right)$ generally varies between 25 and $50 \%$ (Fig. 8ii). However, there are extended oceanic areas (e.g. Pacific, South Altantic, Indian ocean) with values up to $70 \%$. This is due to the comparatively stronger absorption 

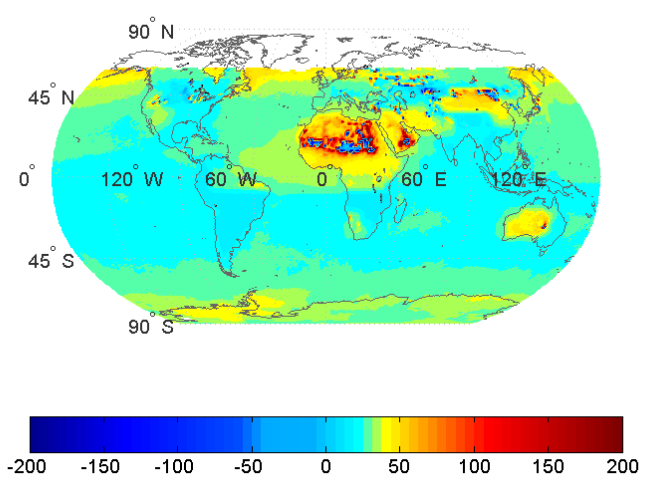

(i-a)
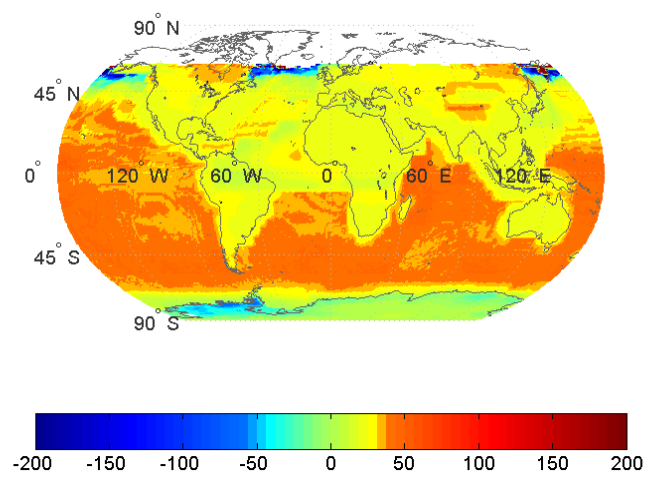

(ii-a)
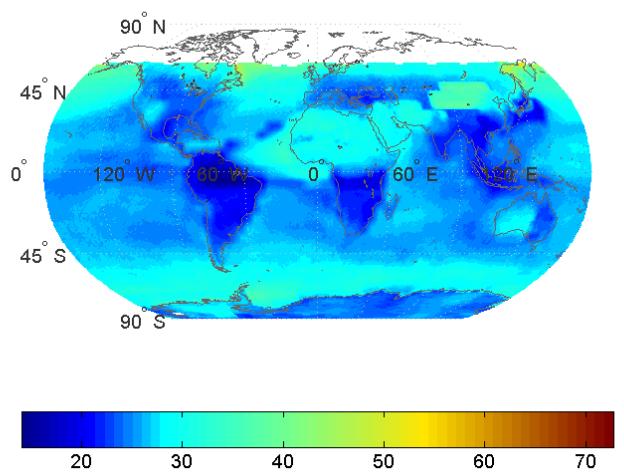
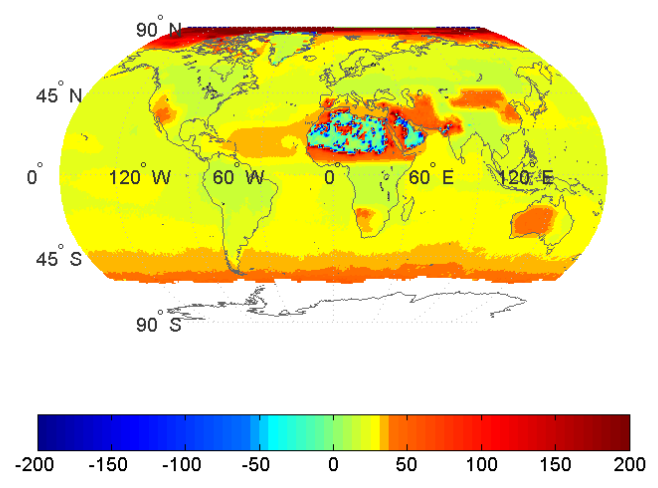

(i-b)
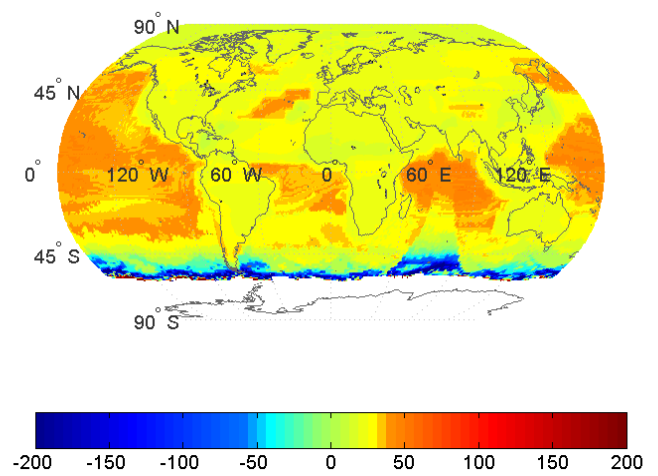

(ii-b)

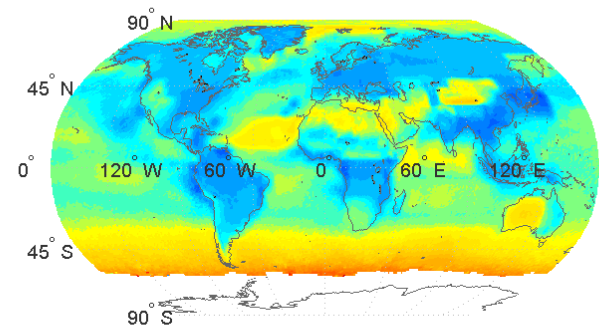

(iii-b)

Fig. 8. Percent contribution of near-IR to the total SW aerosol direct radiative effect at: (i) $\mathrm{TOA}\left(\Delta F_{\mathrm{TOA}}^{\text {near-IR }} / \Delta F_{\mathrm{TOA}}^{\text {total}-\mathrm{SW}}\right)$, (ii) in the atmosphere $\left(\Delta F_{\text {atmab }}^{\text {near-IR }} / \Delta F_{\text {atmab }}^{\text {total-SW }}\right)$, and (iii) at surface $\left(\Delta F_{\text {surfnet }}^{\text {near-IR }} / \Delta F_{\text {surfnet }}^{\text {total-SW }}\right)$, for (a) January and (b) July.

of near-IR than UV-visible radiation by sea-salt aerosols (remote - pure oceanic) because of the increasing imaginary part of refractive index towards near-IR wavelengths (Koepke et al., 1997), opposite to aerosol populations with anthropogenic components. Note that over specific regions (e.g. western part of Antarctica, middle-to-polar oceanic regions of the Northern Hemisphere) there are negative values, i.e. the atmosphere over those areas absorbs less near-IR radiation than it would do without aerosols included. This can occur when an aerosol layer, with a critical particle concentration, extends high up in the atmosphere, preventing thus penetration and absorption of radiation in the lower atmosphere. 


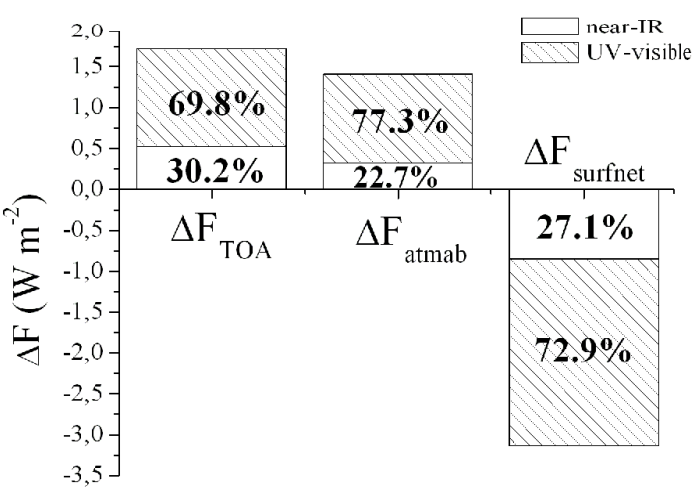

(a)

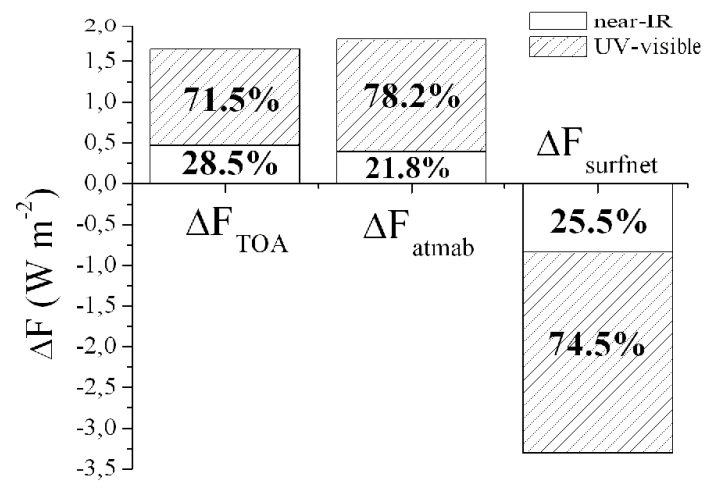

(b)

Fig. 9. Absolute and percent contribution of globally averaged nearIR and UV-visible aerosol direct radiative effects (DRE) to the total SW aerosol DRE at: TOA $\left(\Delta \mathrm{F}_{\mathrm{TOA}}\right)$, in the atmosphere $\left(\Delta \mathrm{F}_{\mathrm{atmab}}\right)$, and at surface $\left(\Delta \mathrm{F}_{\text {surfnet }}\right)$, for (a) January and (b) July.

The contribution of near-IR aerosol DRE at the surface to the total SW DRE, has in general values varying within the range $20-30 \%$. Only over limited regions this contribution can be larger (up to about 50\%). Note that contributions of near-IR to total SW aerosol DRE at surface as large as $45 \%$ have been reported from measurements during the INDOEX and ACE-Asia experiments on the local spatial scale and diurnal resolution, for a spectral coverage starting at $0.68 \mu \mathrm{m}$ instead of $0.85 \mu \mathrm{m}$ in our study. Nishizawa et al. (2004), from 2-year measurements in Japan, reported that the UVvisible aerosol forcing at the surface is almost 4 times larger than in near-IR, in agreement with our results. According to our study, on a global scale, the stronger radiative effect of aerosols on surface solar radiation lies in the UV-visible wavelengths, being larger than in the near-IR by a factor of 2.5 to 4 . The fraction of total SW aerosol DRE contributed by the near-IR is somewhat smaller than the corresponding fraction of the total SW flux contributed by the near-IR (about
40\%). This indicates that the two broad spectral intervals of the total solar spectrum (i.e. the UV-visible and the nearinfrared) are affected by aerosols to a different extent.

On mean global basis, the near-IR aerosol DRE components (at TOA, in the atmosphere, and at surface) are found to contribute to the corresponding total solar DRE, by a percentage varying within the range $22-30 \%$, depending on the DRE component and the season (Fig. 9). The near-IR contribution for DRE at TOA $\left(\triangle \mathrm{F}_{\mathrm{TOA}}\right)$ is about $30 \%$, for the atmospheric DRE $\left(\Delta \mathrm{F}_{\mathrm{atmab}}\right)$ it is about $22 \%$, whereas for the surface DRE $\left(\Delta \mathrm{F}_{\text {surfnet }}\right)$ it is about $27 \%$. Overall, the largest relative contribution of near-IR to total SW aerosol DRE is found for $\Delta \mathrm{F}_{\mathrm{TOA}}$, and the smallest for $\Delta \mathrm{F}_{\mathrm{atmab}}$. The contribution is larger in January than in July, for all DREs.

\section{Sensitivity of aerosol direct radiative effect to the wavelength dependence of aerosol optical properties}

In order to assess the sensitivity of aerosol DREs to the wavelength dependence of aerosol optical properties, we have performed detailed sensitivity tests with our model, in which the averaged near-IR GADS aerosol optical properties were used in the model instead of the spectral ones used to compute the aerosol DREs presented in this study. The results of these sensitivity tests for the aerosol DREs at TOA, in the atmosphere, and at the Earth's surface and $\left(\Delta \mathrm{F}_{\mathrm{TOA}}, \Delta \mathrm{F}_{\text {atmoab }}\right.$ and $\Delta \mathrm{F}_{\text {surfnet }}$, respectively) are shown in Fig. 10. The forcing sensitivities (in absolute and percentage terms) are defined as follows

$$
\begin{aligned}
& \Delta \Delta F_{i}=\Delta F_{\text {spectral }}-\Delta F_{\text {broadband }} \\
& \Delta \Delta F_{i} \%=\frac{\Delta \Delta F_{i}}{\Delta F_{\text {spectral }}} \times 100
\end{aligned}
$$

where $\Delta \mathrm{F}_{\text {spectral }}$ and $\Delta \mathrm{F}_{\text {broadband }}$ are the aerosol DREs computed using detailed spectral and spectrally averaged near-IR aerosol optical properties. According to Eq. (14) positive/negative values of $\Delta \Delta \mathrm{F}_{i}$ involve underestimation/overestimation of the computed $\Delta \mathrm{F}_{i}$ using spectrally averaged aerosol optical properties with respect to those obtained using detailed spectral properties.

For the DRE in the atmosphere ( $\left.\Delta \mathrm{F}_{\text {atmoab }}\right)$ according to our results, there is generally larger sensitivity over ocean than land (Fig. 10b). Using spectrally averaged aerosol optical properties instead of detailed ones leads to a significant underestimation over ocean (differences spectral minus broadband $\Delta \Delta \mathrm{F}_{\text {atmoab }}$ up to $300 \%$ ), but also over land $\left(\Delta \Delta \mathrm{F}_{\text {atmoab }}\right.$ up to $\left.100 \%\right)$. Especially, large underestimation of $\Delta \mathrm{F}_{\text {atmoab }}$ is obtained over areas dominated by coarse desert dust particles. Nevertheless, a significant overestimation (negative values of $\Delta \Delta \mathrm{F}_{\mathrm{atmoab}}$ ) is obtained as well over limited areas off the Antarctica coasts in January, and in some northern parts of the storm-track zone of Southern Hemisphere in July. In general, the sensitivity of $\Delta F_{\text {atmoab }}$ 

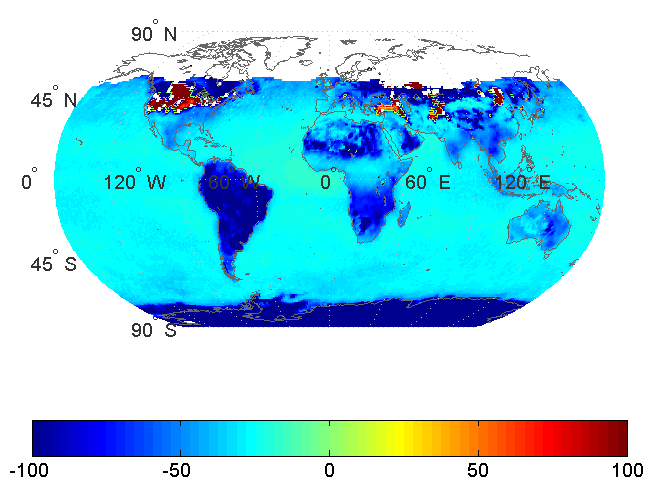

(i-a)
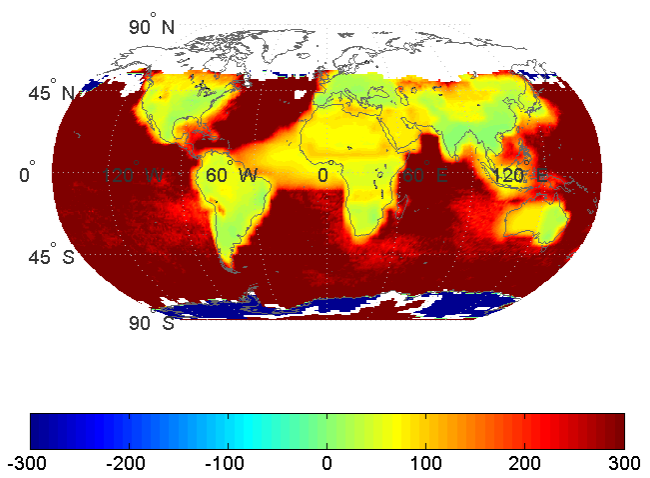

(ii-a)

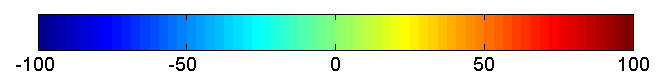

(i-b)
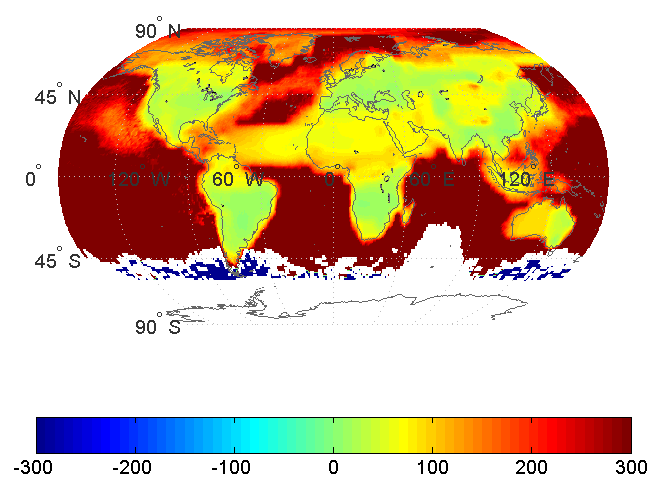

(ii-b)
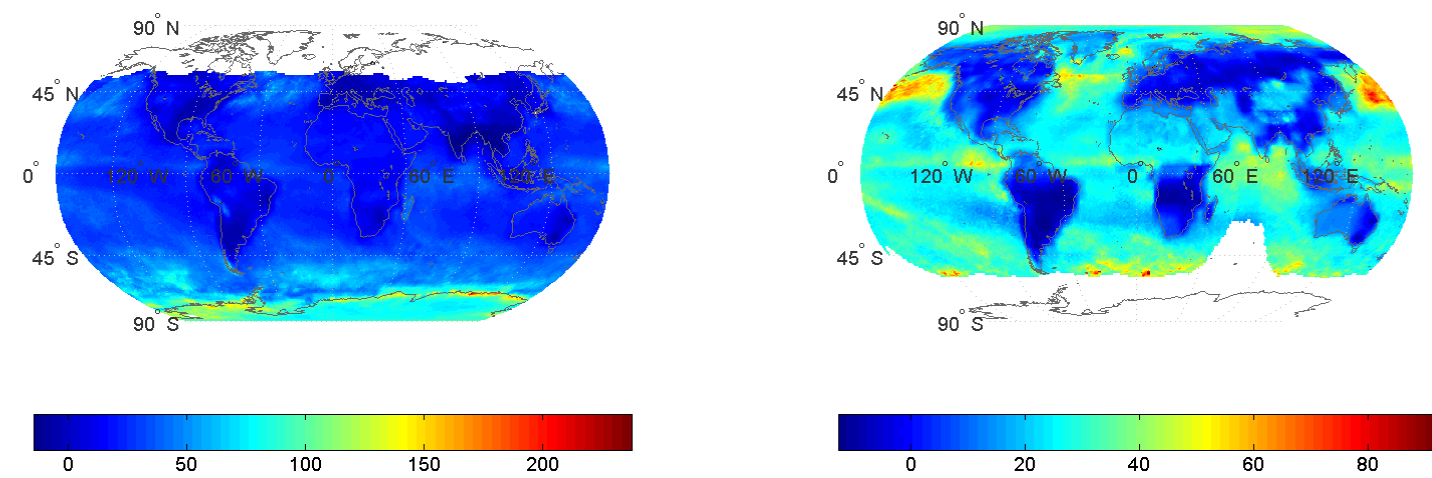

(iii-a)

Fig. 10. Global distribution of percentage differences $(\Delta \Delta \mathrm{F}$ in $\%)$ in the reference aerosol direct radiative effects $\Delta \mathrm{F}$, for (a) January and (b) July, produced by using averaged near-IR aerosol optical properties (AOT, extinction aerosol optical thickness; $\omega_{\text {aer, }}$, aerosol single scattering albedo; $g_{\text {aer }}$, aerosol asymmetry parameter) instead of the spectral ones (reference DREs).

is found to be largest over areas with coarse desert dust or maritime aerosols, whereas it is smaller over areas with fine aerosols (e.g. America, Europe, South and South-East Asia, eastern Australia). This can be explained by the fact that the values of absorption AOT (and coefficient) in the near-IR wavelengths are quite smaller for the fine than coarse aerosol types (see e.g. Almeida et al., 1991). This dominates actually the stronger spectral decrease of AOT in the near-IR wavelengths for the fine than coarse aerosols. 
Table 2. Differences $\left(\Delta \Delta \mathrm{F}\right.$ in $\left.\mathrm{W} \mathrm{m}^{-2}\right)$ in model mean annual global and hemispherical $(\mathrm{NH}, \mathrm{SH})$ all-sky near-IR aerosol direct radiative effects $\Delta \mathrm{F}$ (in $\mathrm{W} \mathrm{m}^{-2}$ ), for January and July, produced by using averaged near-IR aerosol optical properties (AOT, extinction aerosol optical thickness; $\omega_{\text {aer }}$, aerosol single scattering albedo; $g_{\text {aer }}$, aerosol asymmetry parameter) instead of the spectral ones (reference DREs). The forcings are explained in Table 1 . The forcing changes $\Delta \Delta \mathrm{F}$ in parentheses are given as percentage changes of the reference-case DREs.

\begin{tabular}{lllll}
\hline & & $\Delta \Delta \mathrm{F}_{\mathrm{TOA}}$ & $\Delta \Delta \mathrm{F}_{\text {atmab }}$ & $\Delta \Delta \mathrm{F}_{\text {surfnet }}$ \\
\hline \multirow{4}{*}{ January } & Globe & $-0.22(-44.0)$ & $0.41(132.2)$ & $-0.24(24.5)$ \\
& North Hemisphere & $-0.22(-39.23)$ & $0.39(86.7)$ & $-0.20(16.1)$ \\
& South Hemisphere & $-0.23(-53.5)$ & $0.43(268.7)$ & $-0.28(38.9)$ \\
\hline \multirow{4}{*}{ July } & Globe & $-0.19(-43.18)$ & $0.33(84.6)$ & $-0.56(56.6)$ \\
& North Hemisphere & $-0.28(-50.0)$ & $0.49(72.1)$ & $-0.26(17.4)$ \\
& South Hemisphere & $-0.10(-30.3)$ & $0.18(163.6)$ & $-0.86(172.0)$ \\
\hline
\end{tabular}

As for the sensitivity of the aerosol direct radiative effect at TOA $\left(\triangle \mathrm{F}_{\mathrm{TOA}}\right.$, Fig. $\left.10 \mathrm{a}\right)$ it is found that using spectrallyaveraged aerosol optical properties in the near-IR spectral range, instead of detailed ones, results mostly in an overestimation of $\Delta \mathrm{F}_{\mathrm{TOA}}$ over the globe (negative values of $\left.\Delta \Delta \mathrm{F}_{\mathrm{TOA}}\right)$. Differences up to $-100 \%$ are computed over extended continental world regions (North and South America and Africa, Europe, South and South-East Asia, Antarctica in January and Arctic in July), whereas the differences $\Delta \Delta \mathrm{F}_{\mathrm{TOA}}$ over ocean are generally smaller than $-40 \%$. The obtained differences are attributed to the spectral behaviour of the extinction and scattering coefficients and of AOT in combination with their magnitude. More specifically, the spectral variation of scattering and extinction coefficients for maritime aerosols is smaller than for continental ones. Apart from the general overestimation when using spectrally averaged aerosol optical properties, there appear also some limited geographical regions (over the USA and part of MiddleEast in January, Greenland and small areas in North Africa in July) where our computations indicate underestimation (positive values of $\Delta \Delta \mathrm{F}_{\mathrm{TOA}}$ ).

As a result of differences in $\Delta \mathrm{F}_{\mathrm{TOA}}$ and $\Delta \mathrm{F}_{\text {atmoab }}$, between using spectrally-averaged and detailed spectral aerosol optical properties in the radiative transfer model, large differences are also found for the aerosol DRE on surface solar radiation $\left(\Delta \Delta \mathrm{F}_{\text {surfnet }}\right.$, Fig. 10c). Note that mostly underestimation of $\Delta F_{\text {surfnet }}$ (positive values of $\Delta \Delta F_{\text {surfnet }}$ ) is obtained over the globe using spectrally-averaged aerosol optical properties. In July, the underestimation predominates over much of the globe, being as large as 90\%. Relatively large underestimation (of about 50\%) is obtained over oceanic areas, whereas small overestimation (about -20\%) appears over specific continental areas (eastern USA, southern America and Africa, Europe, Siberia). Similar patterns are found for January, when a strong underestimation (150$200 \%$ ) of $\Delta \mathrm{F}_{\text {surfnet }}$ is found in Antarctica's coastal areas.

Table 2 diplays the hemispherical and global averages of differences in aerosol DREs $(\Delta \Delta \mathrm{F})$ at TOA, in the atmosphere and at the surface $\left(\Delta \mathrm{F}_{\mathrm{TOA}}, \Delta \mathrm{F}_{\text {atmoab }}\right.$ and $\Delta \mathrm{F}_{\text {surfnet }}$, respectively) between using detailed spectral and spectrallyaveraged aerosol optical properties. The sensitivities are given in absolute terms (in $\mathrm{W} \mathrm{m}^{-2}$ ) whereas relative percentage changes of the reference aerosol DREs $\left(\Delta \mathrm{F}_{\text {spectral }}\right)$ are also provided. As expected, in general, stronger absolute sensitivities are found in the summer hemisphere, which is an indication of the important role of the incoming solar radiation. Overall, the sensitivity in computations of aerosol DREs is very large for all components, i.e. at TOA, in the atmosphere and at the surface. Using spectrally-averaged aerosol optical properties produces very important underestimations and overestimations of aerosol DREs, depending on the aerosol DRE, the hemisphere and the season. The values of these differences range from 16 to $270 \%$ in terms of relative percentage differences (absolute values ranging from -0.1 to $-0.86 \mathrm{~W} \mathrm{~m}^{-2}$ ). The relative percentage differences $\Delta \Delta \mathrm{F}$ of near-IR aerosol DREs obtained in the present study are even larger than the corresponding differences for the UV-visible aerosol DREs (see Hatzianastassiou et al., 2004b) but they are smaller in terms of absolute values. Our results indicate that it is important to use detailed spectrally resolved aerosol optical properties in the computation of their direct radiative effects.

\section{Conclusions}

We used a detailed spectral radiative transfer model together with spectral aerosol optical properties to compute the direct radiative effect (DRE) of aerosols on the solar near-IR $(\lambda \geq 0.85 \mu \mathrm{m})$ radiation budget. We estimated the effect of natural plus anthropogenic aerosols on the outgoing near-IR radiation at the top of atmosphere, on atmospheric absorption, and on the downward and absorbed near-IR radiation at the Earth's surface. The model computations were performed under all-sky conditions, using realistic data for all surface and atmospheric parameters, for the 12 years 19841995. The aerosol data (optical thickness, single scattering albedo and asymmetry parameter) were taken from the 
Global Aerosol Data Set (GADS) and were subsequently recomputed for realistic relative humidity values of the aerosol layer. The results are given for January and July at $1^{\circ}$ latitude-longitude resolution, but also averaged for the two hemispheres and for the globe.

Our results demonstrate the importance of performing computations with radiative transfer models using spectrally resolved aerosol optical properties to assess aerosol radiative effects instead of using spectral averages. This was verified through sensitivity tests performed with our model using detailed spectral and spectrally-averaged aerosol optical properties. The differences obtained in the computed aerosol DREs were very large, exceeding $30 \%$ over most areas of the globe for the aerosol DRE at TOA, 75\% for the aerosol DRE in the atmosphere, and 20\% for the aerosol DRE at surface, whereas even much larger differences, reaching $300 \%$ in relative percentage terms, were found for specific regions. The absolute differences on a mean hemispherical and global basis, reach values up to $-0.28,0.49$ and $-0.86 \mathrm{~W} \mathrm{~m}^{-2}$ for the aerosol DREs at TOA, in the atmosphere and the surface, respectively. The corresponding relative percentage differences are as large as $-53 \%, 268 \%$ and $172 \%$.

On a mean global basis, aerosols are found to increase the outgoing near-IR radiation at TOA (planetary cooling) by about $0.5 \mathrm{~W} \mathrm{~m}^{-2}$, and to radiatively heat the atmosphere by increasing the absorption of near-IR radiation by about $0.4 \mathrm{~W} \mathrm{~m}^{-2}$. As a result, the absorbed near-IR radiation by the Earth's surface is found to be decreased (surface cooling) by $0.9 \mathrm{~W} \mathrm{~m}^{-2}$, due to aerosols.

At the regional (pixel) level, it is found that in general, aerosols cool the Earth-atmosphere system, through scattering of near-IR radiation back to space, by up to $6 \mathrm{~W} \mathrm{~m}^{-2}$. The largest near-IR cooling effect takes place over desert areas such as Sahara, as well as over oceanic regions with dust transport (e.g. tropical Atlantic). Beyond the general planetary cooling, aerosols are also found to produce warming (by up to $1 \mathrm{~W} \mathrm{~m}^{-2}$ ) over Greenland in July and over limited areas in the Sahara. According to our results, the aerosol particles warm the atmosphere, except for some rare cases, by absorbing near-IR radiation (by up to $7 \mathrm{~W} \mathrm{~m}^{-2}$ ). The largest aerosol-produced near-IR atmospheric warming occurs above areas characterized by strongly absorbing mineral dust particles, especially over highly reflecting deserts. Over some regions, such as the western Antarctic or the windy zone of the Southern Hemisphere, aerosols are found to slightly decrease atmospheric absorption of near-IR radiation (atmospheric cooling). The strongest effect of aerosols is found at the surface, where the downward and absorbed near-IR radiation is decreased by up to 12 and $10 \mathrm{~W} \mathrm{~m}^{-2}$, respectively, due to aerosol scattering and absorption. The near-IR aerosol DRE at the surface is larger than at TOA by a factor of 3 to 4 , which indicates the important role of aerosols for surface processes and the surface radiation budget.

The aerosol-produced surface near-IR cooling combined with an associated atmospheric warming, produces a signif- icant aerosol effect on the thermal dynamics (AETD) of the Earth-atmosphere system. This radiative effect was quantified by the difference $A E T D=\Delta F_{\text {atmab }}-\Delta F_{\text {surfnet }}$, and found to be up to 13 and $16 \mathrm{~W} \mathrm{~m}^{-2}$ for January and July, respectively, being largest over deserts and surrounding semi-arid regions. Aerosol-produced changes in the near-IR energy distribution between the Earth's surface and the atmosphere is important for atmospheric dynamics, since it can create more stable atmospheric conditions and lower surface evaporation, resulting in less clouds and precipitation, thus enhancing desertification processes, especially in semi-arid regions such as the Mediterranean basin.

Our modelling study indicates that the near-IR aerosol DRE is generally smaller in magnitude than the corresponding DRE in the UV-visible, and contributes to the total SW aerosol DRE by about $30 \%$. This relative contribution is largest for the TOA DRE, and smallest for the atmospheric DRE. Moreover, on a regional basis, the near-IR DRE can be larger than the UV-visible, whereas over specific regions (Sahara, Arctic in July) it can even have opposite sign. This indicates that it is very important to perform detailed spectral computations of aerosol radiative effects (and forcings), including the near-IR range, in order to asses the climatic role of aerosols.

Acknowledgements. This research was co-funded by the European Social Fund \& National Resources-EPEAEK II - PYTHAGORAS (contract: 1964). The NASA-Langley data were obtained from the NASA Langley Research Center (LaRC) Atmospheric Sciences Data Center (ASDC). The GADS aerosol data were obtained from the Meteorological Institute of the University of Munich, Germany: (http://www.meteo.physik.uni-muenchen.de/strahlung/aerosol/ aerosol.htm).

Edited by: A. Nenes

\section{References}

Allison, I.: East Antarctic sea ice: Albedo, thickness distribution, and snow cover, J. Geophys. Res., 98, 12 417-12 429, 1993.

Bellouin, N., Boucher, O., Haywood, J., and Reddy, M. S.: Global estimate of aerosol direct radiative forcing from satellite measurements, Nature, 438, 1138-1141, 2005.

Bush, B. C. and Valero, F. P. J.: Surface aerosol radative forcing at GOSAN during the ACE-Asia campaign, J. Geophys. Res., 108(D23), 8660, doi:10.1029/2002JD003233, 2003.

Carlson, T. N. and Benjamin, S. G.: Radiative heating rates for Saharan dust, J. Atmos. Sci., 37, 193-213, 1980.

Chin, M., Ginoux, P., Kinne, S., Torres, O., Holben, B. N., Duncan, B. N., Martin, R. V., Logan, J. A., Higurashi, A., and Nakajima, T.: Tropospheric aerosol optical thickness from the GOCART model and comparisons with satellite and Sun photometer measurements, J. Atmos. Sci., 59, 461-483, 2002.

Christopher, S. A. and Zhang, J.: Shortwave aerosol radiative forcing from MODIS and CERES observations over the oceans, Geophys. Res. Lett., 29, 1859, doi:10.1029/2002GL014803, 2002. 
D'Almeida, G. A., Koepke, P., and Shettle, E. P.: Atmospheric aerosols: Global climatology and radiative characteristics, 560 pp., A. Deepak Publishing, Hampton, Virginia, USA, 1991.

Formenti P., Elbert, W., Maenhaut, W., Haywood, J., and Andreae, M. O.: Chemical composition of mineral dust aerosol during the Saharan Dust Experiment (SHADE) airborne campaign in the Cape Verde region, September 2000, J. Geophys. Res., 108(D18), 8576, doi:10.1029/2002JD002648, 2003.

Hansen, J., Russell, G., Rind, D., Stone, P., Lacis, A., Lebedeff, S., Ruedy, R., and Travis, L.: Efficient three-dimensional global models for climate: Models I and II, Mon. Wea. Rev., 111, 609$662,1983$.

Hartmann, D. L.: Global Physical Climatology, Academic Press, 411 pp, 1994.

Hatzianastassiou, N., Katsoulis, B., and Vardavas, I.: Global distribution of aerosol direct radiative forcing in the ultraviolet and visible arising under clear skies, Tellus, 56B, 51-71, 2004a.

Hatzianastassiou, N., Katsoulis, B., and Vardavas, I.: Sensitivity analysis of aerosol direct radiative forcings in the ultraviolet visible wavelengths and consequences for the heat budget, Tellus, 56B, 368-381, 2004b.

Hatzianastassiou, N., Fotiadi, A., Matsoukas, C., Drakakis, E., Pavlakis, K. G., Hatzidimitriou, D., and Vardavas, I.: A 17-year global distribution of Earth's surface shortwave radiation budget, Atmos. Chem. Phys., 5, 2847-2867, 2005,

http://www.atmos-chem-phys.net/5/2847/2005/.

Haywood, J. M. and Shine, K. P.: Multi-spectral calculations of the radiative forcing of tropospheric sulphate and soot aerosols using a column model, Quart. J. Roy. Meteorol. Soc., 123, 1907-1930, 1997.

Haywood, J. M. and Ramaswamy, V.: Global sensitivity studies of the direct radiative forcing due to anthropogenic sulfate and black carbon aerosols, J. Geophys. Res., 103, 6043-6058, 1998.

Hess, M., Koepke, P., and Schult, I.: Optical properties of aerosols and clouds: The software package OPAC, Bull. Am. Meteorol. Soc., 79, 831-844, 1998.

Intergovernmental Panel on Climate Change (IPCC): Climate Change 2001, The Scientific Basis, 881 pp., edited by: Houghton J. T., Ding, Y., Griggs, D. J., et al., Cambridge Univ. Press, New York, 2001.

Jacobson, M. Z.: Global direct radiative forcing due to multicomponent anthropogenic and natural aerosols, J. Geophys. Res., 106, 1551-1568, 2001.

Jaenicke, R.: Tropospheric aerosols, in: Aerosol-Cloud-Climate Interactions, edited by: P. Hobbs, pp. 1-31, Academic, San Diego, Calif., 1993.

Joseph, J. H., Wiscombe, W. J., and Weinmann, J. A.: The DeltaEddington approximation of radiative flux transfer, J. Atmos. Sci., 33, 2452-2459, 1976.

Kaufman, Y. J., Tanré, D., Dubovik, O., Karnieli, A., and Remer, L. A.: Absorption of sunlight by dust as inferred from satellite and ground-based measurements, Geophys. Res. Lett., 28, 14791482, 2001.

Kaufmann, Y. J., Tanré, D., and Boucher, O.: A satellite view of aerosols in the climate system, Nature, 419, 215-223, 2002.

Keil, A. and Haywood, J.: Solar radiative forcing by biomass burning aerosol particles during SAFARI-2000: A case study based on measured aerosol and cloud properties, J. Geophys. Res., 108(D13), 8467, doi:10.1029/2002JD002315, 2003.
King, M. D., Kaufmann, Y. J., Tanré, D., and Nakajima, T.: Remote sensing of tropospheric aerosols from space: Past, present, and future, Bull. Am. Meteorol. Sos., 80, 2229-2259, 1999.

Kinne, S., Lohmann, U., Feichter, J., Schulz, M., et al.: Monthly averages of aerosol properties: A global comparison among models, satellite data, and AERONET ground data, J. Geophys. Res., 108(D20), 4634, doi:10.1029/2001JD001253, 2003.

Koepke, P., Hess, M., Schult, I., and Shettle, E. P.: Global aerosol data set. Rep. No 243, Max-Planck Institut für Meteorologie, 44 pp., Hamburg, Germany, 1997.

Lelieveld, L., Berresheim, H., Borrmann, S., et al.: Global air pollution crossroads over the Mediterranean, Science, 298, 794-799, 2002.

Liao, H., Seinfeld, J. H., Adams, P. J., and Mickley, L. J.: Global radiative forcing of coupled tropospheric ozone and aerosols in a unified general circulation model, J. Geophys. Res., 109, D16207, doi:10.1029/2003JD004456, 2004.

Ming, Y., Ramaswamy, V., Ginoux, P. A., and Horowitz, L. H.: Direct radiative forcing of anthropogenic organic aerosols, J. Geophys. Res., 110, D20208, doi:10.1029/2004JD005573, 2005.

Morcrette, J.-J.: The surface downward longwave radiation in the ECMWF forecast system, J. Climate, 15, 1875-1992, 2002.

Nishizawa, T., Asano, S., Uchiyama, A., and Yamazaki, A.: Seasonal variation of aerosol direct radiative forcing and optical properties estimated from ground-based solar radiation measurements, J. Atmos. Sci., 61, 57-72, doi:10.1175/15200469(2004)061, 2004.

Reddy, M. S., Boucher, O., Bellouin, N., Schulz, M., Balkanski, Y., Dufresne, J.-L., and Pham, M.: Estimates of global multicomponent aerosol optical depth and direct radiative perturbation in the Laboratoire de Météorologie Dynamique general circulation model, J. Geophys. Res., 110, D10S16, doi:10.1029/2004JD004757, 2005.

Remer, L. A. and Kaufman, Y. J.: Aerosol direct radiative effect at the top of the atmosphere over cloud free ocean derived from four years of MODIS data, Atmos. Chem. Phys., 6, 237-253, 2006, http://www.atmos-chem-phys.net/6/237/2006/.

Roesch, A., Wild, M., Pinker, R., and Ohmura, A.: Comparison of surface spectral albedos and their impact on the general circulation model estimated surface climate, J. Geophys. Res., 107(D14), ACL 13-1-ACL 13-8, doi:10.1029/2001JD000809, 2002.

Rossow, W. B., Walker, A. W., Beuschel, D. E., and Roiter, M. D.: International Satellite Cloud Climatology Project (ISCCP). Documentation of new cloud datasets, 115 pp., Wold Meteorol. Org. Geneva, 1996.

Shettle, E. P. and Weinmann, J. A.: The transfer of solar irradiance through inhomogeneous turbid atmospheres evaluated by Eddington's approximation, J. Atmos. Sci., 27, 1048-1055, 1970.

Sokolik, I. N., Andronova, A., and Johnson, T. C.: Complex refractive index of atmospheric dust aerosols, Atmos. Environ., 27A(16), 2495-2502, 1993.

Sokolik, I. N. and Toon, O. B.: Incorporation of mineralogical composition into models of the radiative properties of mineral aerosol from UV to IR wavelengths, J. Geophys. Res., 104(D8), 94239999, 1999.

Stackhouse, P. W., Gupta, S. K., Cox, S. J., Mikowitz, C., and Chiacchio, M.: New results from the NASA/GEWEX Surface Radiation Budget project: Evaluating El Nino effects at different 
scales, 11th American Meteorological Society Conference on Atmospheric Radiation, Ogden, UT, USA, P.3.6, 2002.

Takemura, T., Nakajima, T., Dubovik, O., Holben, B. N., and Kinne, S.: Single-scattering albedo and radiative forcing of various aerosol species with a global three-dimensional model, J. Climate, 15, 333-352, 2005.

Thekaekara, M. P. and Drummond, A. J.: Standard values for the solar constant and its spectral components, Nature Phys. Sci., 229, 6-9, 1971.

Valero, F. P. J., Bush, B. C., Pope, S. K., Marsden, D. C., and Leitner, A. S.: Aerosol forcing during INDOEX and ACE-Asia as determined from aircraft and ground measurements, Geophys. Res. Abstr., 5, 01607, 2003.

Vardavas, I. and Carver, J. H.: Solar and terrestrial parameterizations for radiative convective models, Planet. Space Sci., 32, 1307-1325, 1984.

Vardavas, I. and Koutoulaki, K.: A model for the solar radiation budget of the northern hemisphere: Comparison with Earth Radiation Budget Experiment data, J. Geophys. Res., 100, 73037314, 1995.
Willson, R. C.: Total solar irradiance trend during solar cycles 21 and 22, Science, 277, 1963-1965, 1997.

Yu, H., Kaufman, Y. J., Chin, M., Feingold, G., Remer, L. A., Anderson, T. L., Balkanski, Y., Bellouin, N., Boucher, O., Christopher, S., DeCola, P., Kahn, R., Koch, D., Loeb, N., Reddy, M.S., Schulz, M., Takemura, T., and Zhou, M.: A review of measurement-based assessment of aerosol direct radiative effect and forcing, J. Geophys. Res., 109, D03206, doi:10.1029/2003JD003914, 2006.

Zhang, J., Christopher, S. A., Remer, L. A., and Kaufman, Y. J.: Shortwave aerosol cloud-free radiative forcing from Terra, II: Seasonal and global distributions, J. Geophys. Res., 110, D10S24, doi:10.1029/2004JD005009, 2005.

Zhao, T. X.-P., Laszlo, I., Minnis, P., and Remer, L.: Comparison and analysis of two aerosol retrievals over the ocean in the Terra/Clouds and the Earth's Radiant Energy System-Moderate Resolution Imaging Spectroradiometer single scanner footprint data: 1. Global evaluation, J. Geophys. Res., 110, D21208, doi:10.1029/2005JD005851, 2005. 